AL.2.2005-188

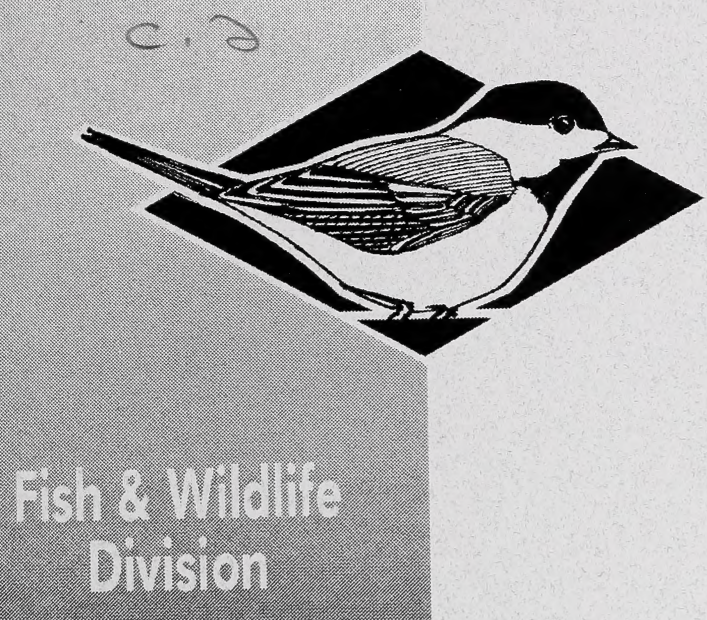

\title{
Status of the Arctic Grayling (Thymallus arcticus) in Alberta
}

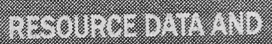

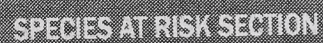

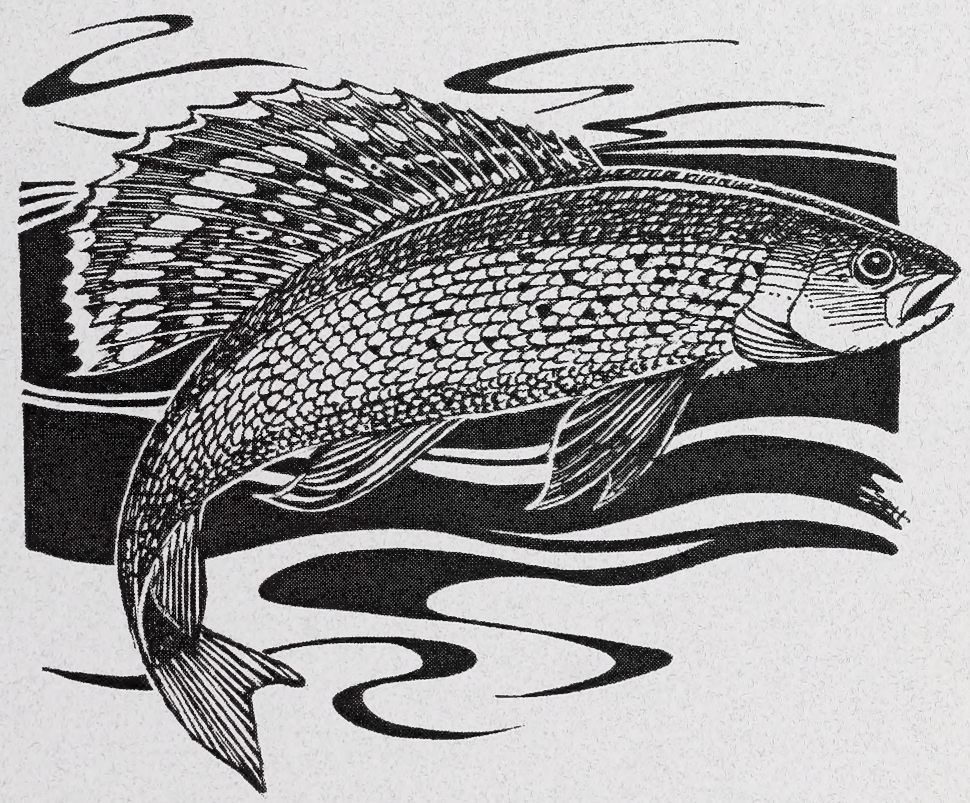

Alberta Wildlife Status Report No. 57

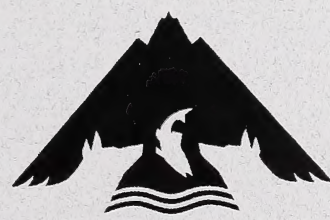

Alberta Conservation Association 



\title{
Status of the Arctic Grayling (Thymallus arcticus) in Alberta
}

\author{
Prepared for: \\ Alberta Sustainable Resource Development (SRD) \\ Alberta Conservation Association (ACA)
}

Prepared by:

\section{Jordan Walker}

This report has been reviewed, revised, and edited prior to publication. It is an SRD/ACA working document that will be revised and updated periodically.

Alberta Wildlife Status Report No. 57

March 2005

Published By:


Alberta Conservation Association 
Publication No. T/070

ISBN: 0-7785-3674-2 (Printed Edition)

ISBN: 0-7785-3675-0 (On-line Edition)

ISSN: 1206-4912 (Printed Edition)

ISSN: 1499-4682 (On-line Edition)

Series Editors: Sue Peters, Nyree Sharp and Robin Gutsell

Illustrations: Brian Huffman

Maps: Jane Bailey

For copies of this report,visit our web site at :

http://www3.gov.ab.ca/srd/fw/speciesatrisk/

and click on "Detailed Status"

$O R$

Contact:

Information Centre - Publications

Alberta Environment/Alberta Sustainable Resource Development

Fish and Wildlife Division

Main Floor, Great West Life Building

9920 - 108 Street

Edmonton, Alberta, Canada T5K 2M4

Telephone: (780) 422-2079

This publication may be cited as:

Alberta Sustainable Resource Development. 2005. Status of the Arctic grayling (Thymallus arcticus) in Alberta. Alberta Sustainable Resource Development, Fish and Wildlife Division, and Alberta Conservation Association, Wildlife Status Report No. 57, Edmonton, AB. 41 pp. 


\section{PREFACE}

Every five years, the Fish and Wildlife Division of Alberta Sustainable Resource Development reviews the general status of wildlife species in Alberta. These overviews, which have been conducted in 1991 (The Status of Alberta Wildlife), 1996 (The Status of Alberta Wildlife) and 2000 (The General Status of Alberta Wild Species 2000), assign individual species "ranks" that reflect the perceived level of risk to populations that occur in the province. Such designations are determined from extensive consultations with professional and amateur biologists, and from a variety of readily available sources of population data. A key objective of these reviews is to identify species that may be considered for more detailed status determinations.

The Alberta Wildlife Status Report Series is an extension of the general status exercise, and provides comprehensive current summaries of the biological status of selected wildlife species in Alberta. Priority is given to species that are At Risk or May Be At Risk in the province, that are of uncertain status (Undetermined), or that are considered to be at risk at a national level by the Committee on the Status of Endangered Wildlife in Canada (COSEWIC).

Reports in this series are published and distributed by the Alberta Conservation Association and the Fish and Wildlife Division of Alberta Sustainable Resource Development. They are intended to provide detailed and up-to-date information that will be useful to resource professionals for managing populations of species and their habitats in the province. The reports are also designed to provide current information that will assist Alberta's Endangered Species Conservation Committee in identifying species that may be formally designated as Endangered or Threatened under Alberta's Wildlife Act. To achieve these goals, the reports have been authored and/or reviewed by individuals with unique local expertise in the biology and management of each species. 


\section{EXECUTIVE SUMMARY}

Arctic grayling (Thymallus arcticus) in Alberta is currently listed as Sensitive in The General Status of Alberta Wild Species 2000 (Alberta Sustainable Resource Development 2001) and it has not been considered by the Committee on the Status of Endangered Wildlife in Canada (COSEWIC). The purpose of this report is to draw together recent and historical information on Arctic grayling in Alberta. The review will provide a basis for assessing current population status and identifying information gaps for future research.

Grayling is a cool water species primarily found in boreal and foothills streams in the Athabasca, Peace and Hay river drainages. These systems represent the southern extent of the species' geographic range, with the exception of remnant populations in the upper Columbia system in Montana.

Population monitoring in Alberta has been quite variable with respect to timing, capture methodology and effort. The results are largely qualitative (i.e., based on relative abundance) with few population estimates having been conducted. Relative measures of abundance that have been applied include angling, electrofishing, and trapping. Historical photos and interviews with long-time anglers, retired biologists, and retired Fish and Wildlife officers have been essential because many populations declined prior to the establishment of management agencies and monitoring programs.

Subpopulations are estimated to have declined predominantly in the 1950 s to 1970 s with $50 \%$ of Alberta's subpopulations declining over $90 \%$ in abundance. These declines probably represent a range contraction of approximately $40 \%$ of the historical range.

A range of factors, acting in a cumulative fashion, have most likely led to the decline of many grayling populations, including high angling catchability coupled with a popular sport fishery, habitat fragmentation caused by improper road culverts, and increases in water temperature as a result of changing climate and land-use practices. Populations have extensively declined in places where these factors have come together, such as streams and rivers along the southern extent of the range. The development of consistent field evaluation methods and long-term research initiatives will be necessary to effectively monitor populations. 


\section{ACKNOWLEDGEMENTS}

I would like to acknowledge the many people who have contributed to the preparation of this report. Special thanks must go to David Park (Alberta Conservation Association), Travis Ripley (Alberta Sustainable Resource Development), Dr. Michael Sullivan (Alberta Sustainable Resource Development) and Michael Bryski (Alberta Environment) for their generous contributions of data and time for discussions.

I extend my thanks to David Park (Alberta Conservation Association), Jim O'Neil (RL\&LEnvironmental Services Ltd./Golder Associates), Nyree Sharp (Alberta Conservation Association), Robin Gutsell (Alberta Sustainable Resource Development), Chris Davis (Alberta Sustainable Resource Development), Travis Ripley (Alberta Sustainable Resource Development), and Carl Hunt (Alberta Sustainable Resource Development - retired) who reviewed this report and provided many constructive comments so it could be improved. I would like to thank Michael Blackburn (Alberta Conservation Association), Kevin Gardiner (Alberta Conservation Association), and Craig Johnson (Alberta Conservation Association) for their assistance in locating and providing much needed survey data. A special thanks to Jim Stelfox (Alberta Sustainable Resource Development) and Terry Clayton (Alberta Sustainable Resource Development) for sharing their expertise on grayling stocking and abundance in the southern part of the province. Ward Hughson (Aquatics Specialist, Jasper National Park) provided valuable insight into the distribution and stocking history of grayling in Jasper National Park.

Preparation of this report was funded by the Wildlife Management Enhancement Program of the Alberta Conservation Association and the Fish and Wildlife Division of Alberta Sustainable Resource Development. 
Digitized by the Internet Archive in 2016 


\section{TABLE OF CONTENTS}

PREFACE iii

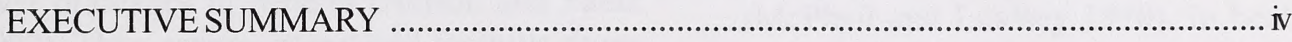

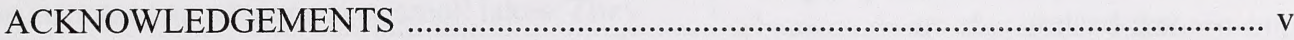

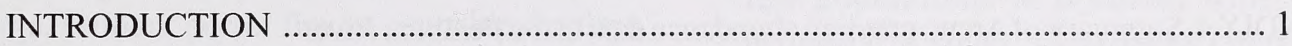

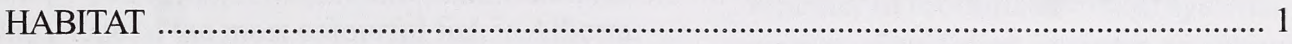

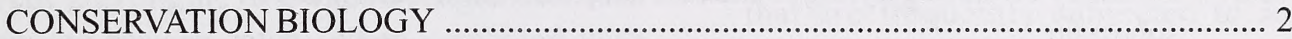

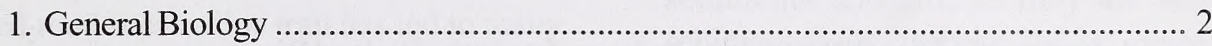

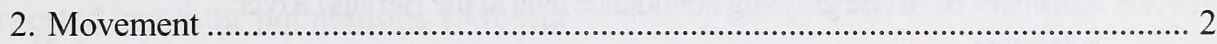

3. Reproductive Biology .................................................................................... 3

4. Growth, Maturity and Age-specific Mortality ……................................................... 4

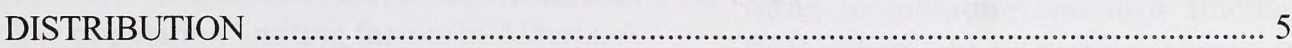

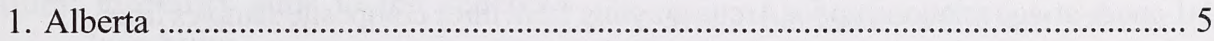

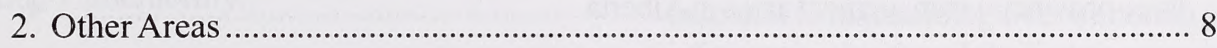

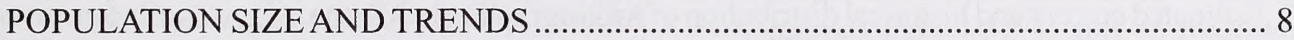

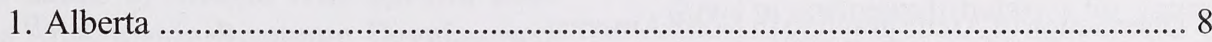

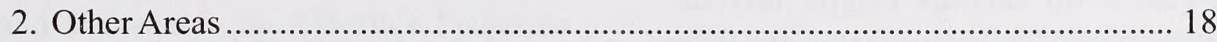

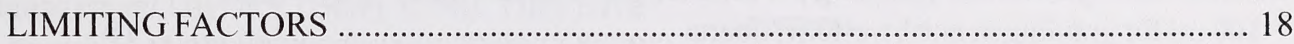

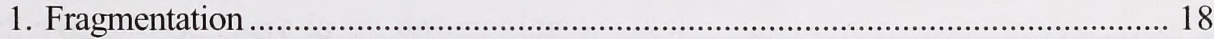

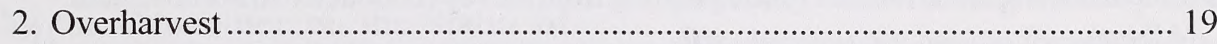

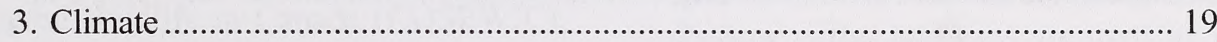

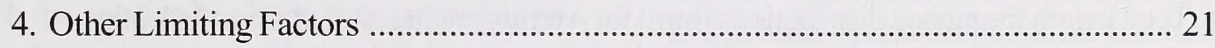

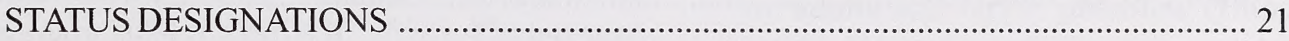

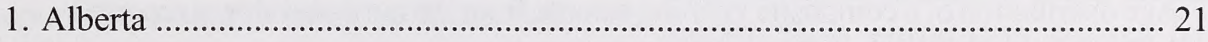

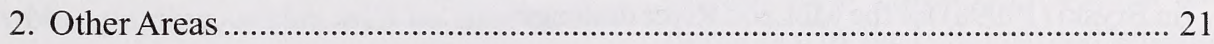

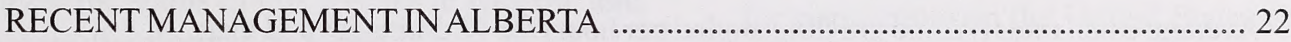

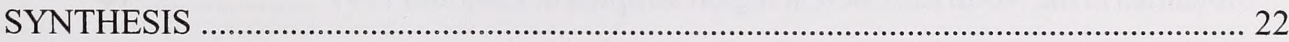

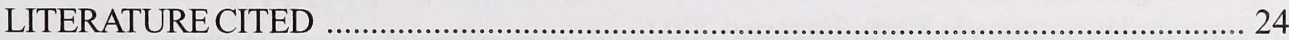


APPENDIX 1 Definitions of selected legal and protective designations

APPENDIX 2 Rivers with grayling subpopulations in Alberta showing probable declines ..... 34

APPENDIX 3 Summary of Arctic grayling abundance data in the McLeod River

sub-basin 35

APPENDIX 4 Summary of Arctic grayling abundance data in the Pembina River sub-basin

APPENDIX 5 Summary of Arctic grayling abundance data in the Little Smoky River sub-basin 39

APPENDIX 6 Summary of Arctic grayling abundance data in the Berland River sub-basin

\section{LIST OF FIGURES}

Figure 1 Length-at-age relationship for Arctic grayling from three composite samples from three provincial management areas in Alberta

Figure 2 Estimated current and historical distribution of Arctic grayling in Alberta 6

Figure 3 Distribution of Arctic grayling in North America

Figure 4 Electrofishing catch rate (grayling per minute) and relative density (grayling per $100 \mathrm{~m}$ ) for grayling in northwestern Alberta

Figure 5 Electrofishing catch rates of Arctic grayling from surveys conducted in northwestern Alberta .

Figure 6 Total length frequency distributions $(\mathrm{mm})$ for Arctic grayling angled from the Little Smoky River, 1988-1997

Figure 7 Age distribution of a composite grayling sample from the northeast slopes reported in Bryski (1999a) for the McLeod River drainage

Figure 8 Average catch rates (Arctic grayling angled per hour) for 12 drainages and their tributaries in the North East Boreal region sampled in 1996 and 1997

Figure 9 Fork length frequency distributions $(\mathrm{mm})$ of Arctic grayling angled from the House River and tributaries in 2000, 2001 and 2002

Figure 10 A comparison of Arctic grayling catchability to other Alberta stream fishes 20

Figure 11 Model of Alberta grayling exploitation at increasing levels of angler effort 20 


\section{INTRODUCTION}

Arctic grayling (Thymallus arcticus) are iridescently colourful fish of the trout family that occur naturally in the Athabasca, Peace, and Hay river drainages in Alberta (Nelson and Paetz 1992). They occupy boreal and foothills rivers and streams and, on occasion, small lakes. They have bright silvery sides and males use their large, brilliant dorsal fins in courtship displays during spring spawning (Scott and Crossman 1985). One of the most colourful fish in Alberta, Arctic grayling are renowned by anglers because they are easy to catch. When combined with increased road access, this trait has led to many overharvested grayling populations (Alberta Energy and Natural Resources 1984; Berry 1998). Habitat fragmentation, sensitivity to warm water temperatures and drought may also be key population limiting factors in Alberta. A high natural mortality adds to the species' population vulnerability.

Arctic grayling are listed as Sensitive* in The General Status of Alberta Wild Species 2000 (Alberta Sustainable Resource Development 2001) and Vulnerable by Alberta's Fisheries Management Division (Berry 1998). They have a Provincial Heritage Status Rank of S5 (NatureServe 2004). There is no designation given by the Committee on the Status of Endangered Wildlife in Canada (COSEWIC), although the species has been categorized as an "intermediate priority candidate" listing as of February 2004 (COSEWIC 2004). The purpose of this report is to compile current information about Arctic grayling, which will be used to update the status of this species in Alberta, and to identify information gaps.

\section{HABITAT}

Arctic grayling populations in Alberta occupy large mainstem rivers and their tributaries, with

* See Appendix 1 for definitions of selected status designations. adult grayling moving between these areas seasonally (Scott and Crossman 1985, Hubert et al. 1985). Generally, in foothills streams, grayling occur in flowing water of moderate gradient that usually remains cool and clear (McPhail and Lindsey 1970). In boreal areas, many populations occur in clear, tannin-stained (brown) rivers that drain northern muskegs. A few populations in northern Alberta occur naturally in small, clear lakes (Berry 1998). Whether in foothills or boreal systems, grayling are not often found in rivers or stream reaches that are frequently subjected to suspended sediments and silt, as they are sensitive to sediment loads (Behnke 2002).

Grayling may occupy streams that drain large wetlands or lakes, perhaps to avoid excessive water temperature and flow fluctuations ( $\mathrm{J}$. Walker, pers. obs.). They may also occur in these areas because sufficient winter flows are essential to maintaining overwintering pools free of in-stream ice for adults in downstream reaches (Stanislawski 1997), and to maintain winter flows in upstream tributaries for young-of-year survival. Highly variable flows may influence adult and juvenile survival, particularly in boreal systems.

Generally, slow-moving tributary margins and side channels are habitat for newly emerged fry, shallow riffles and runs are used by older fry and juveniles, and deeper pools and runs are used by adults and larger juveniles (Hubert et. al. 1985). Habitat suitability index models and instream flow suitability curves have been developed by the U.S. Fish and Wildlife Service for populations in the United States (Hubert et al. 1985).

The rate and extent of habitat fragmentation occurring largely as a result of road construction and other linear developments are a challenge to Arctic grayling populations in Alberta (Tchir et al. in prep., D. Park in prep.) Culverts can become partial or complete barriers over time, which can result in the seasonal or complete 
fragmentation of populations from upstream movements. The factors involved and the extent of this fragmentation on fish populations is currently being studied (Tchir et al. in prep., D. Park in prep.). The densities of stream crossings in the Notikewin and Swan Hills were 0.068 crossings per linear stream kilometre and 0.24 crossings per linear stream kilometre, respectively. Greater than $70 \%$ of crossings in these watersheds were culverts. In the Notikewin and Swan Hills basins it is estimated that hanging culverts limit access to about $9.5 \%$ and $20 \%$ of the watersheds, respectively (Tchir et al. in prep.). Most of the culverts assessed had the potential to fragment stream habitats $(61 \%$ in the Notikewin, and $74 \%$ in the Swan Hills).

Some factors involved are the seasonal timing of the fragmentation as it relates to spawning and overwintering, the vulnerability to angling of grayling gathered in outflow pools next to roads, and the rate of decay of culvert installations (J. Walker, pers. obs.). Quantifying the effect of these factors involved in fragmentation on the persistence of grayling populations still needs to be undertaken. Fundamental genetic research to determine the number of populations, the degree of genetic separation of these populations and the relative risk posed to these populations under varying regimes of fragmentation and other human disturbances is still needed. Rates of recolonization are unknown. (A further discussion is contained in the Limiting Factors section later in this report.)

\section{CONSERVATION BIOLOGY}

1. General Biology - Descriptions of grayling habitats, biology and ecology may be found in Joint and Sullivan (2003), Nelson and Paetz (1992), McPhail and Lindsey (1970), Scott and Crossman (1985) and Behnke (2002).

Young Arctic grayling can be mistaken for young mountain whitefish (Prosopium williamsoni) because young grayling are a silvery grey color, often with parr marks (light banding) along their sides (Nelson and Paetz 1992). However, unlike mountain whitefish, young grayling usually have small dark spots on the sides of their body toward the head, larger dorsal fins, and teeth. Adult grayling (particularly males during spawning) have banded and spotted hues of black, blue, mauve and orange on their dorsal fins (Scott and Crossman 1985). The male's dorsal fin is longer than that of the female, nearly reaching the adipose fin (Scott and Crossman 1985). Spawning males may darken (in some cases becoming black), and develop reddish tails ( $M$. Sullivan, pers. comm.).

Arctic grayling distribute themselves in the watershed according to fish size (Tack 1980, Hughes and Reynolds 1994, Hughes 1999). Larger fish occupy more upstream positions whereas juveniles and smaller fish occupy positions downstream. Arctic grayling are also a schooling fish within pools.

Juvenile and adult grayling are opportunistic, visual feeders, and will feed on drifting aquatic invertebrates such as stoneflies, caddis flies, mayflies and dragonflies, as well as small crustaceans and molluscs (Nelson and Paetz 1992). Grayling will also feed on terrestrial invertebrates such as beetles, midges, ants and grasshoppers, which may make up to $50 \%$ of their diet (Joint and Sullivan 2003).

2. Movement - Within drainages, grayling move upstream and downstream seasonally to use different reaches, and are highly mobile (Tripp and Tsui 1980, Stanislawski 1997). In the Little Smoky River, mature grayling (radio-tagged) moved to downstream reaches in September and October. They moved to deeper overwintering pools possibly to avoid anchor and in-stream ice formations during the winter (Stanislawski 1997). The 30 radio-tagged grayling observed from August 31 to November 16, 1993 moved a mean total distance of $49 \mathrm{~km}$ in the Little Smoky River (Stanislawski 1997). Radio-tagged grayling in the Wapiti system also moved downstream to overwintering locations in the 
mainstem Wapiti River (Tchir et al. 2003). Studies in Alaska have observed grayling to move over $100 \mathrm{~km}$ during migrations (Craig and Poulin 1975, Krueger 1981, Barber et al. 1985, Hop et al. 1986, West et al. 1992 as reported in Stanislawski 1997).

During ice break-up in early May, grayling leave overwintering pools and move upstream to tributaries to spawn. This was observed in the Little Smoky by radio-telemetry, although prior to this study it was believed that the tributaries had been blocked by beaver dams and that they were spawning in the mainstem river (C. Hunt, pers. comm.). In the Wapiti River watershed, grayling movements monitored with telemetry indicated spawning movements to the upper reaches of the Redwillow River during April and early May (Tchir et al. 2003). This seasonal use of habitat has been observed in the Athabasca, Muskeg, Mackay, Steepbank and House rivers (Berry 1998). The Fisheries Management Division defined populations with these movement patterns as "watershed" or "mainstem" populations (Berry 1998). To a lesser extent, there are also "stream resident" populations, associated with boreal streams inundated with beaver dams, which do not migrate downstream. Beaver dams provide important overwintering pools for these populations and are likely involved in restricting downstream movements. Narrows Creek, Martin River and Assineau River populations are examples of stream resident populations (Berry 1998). As in many other salmonids, there appears to be a genetic component to the migration behaviour of the "watershed" populations. But of these two behaviours, "resident" or "watershed", it is difficult to know the extent to which fish behaviour is genetically predetermined and how much is a function of the range of options the environment provides them. The fact that stream resident stocks occupy boreal streams that are inundated with beaver dams suggests that the fish may be trapped in these areas on a semi-permanent to permanent basis (J. O'Neil, pers. comm). This would occur if access to these reaches were prevented by beaver dams (impeded upstream movements of spawners, and downstream dispersal). The beaver impoundments may allow overwinter survival in some of these systems that have suitable overwintering oxygen conditions ( $\mathrm{J}$. O'Neil, pers. comm.).

3. Reproductive Biology - Spawning takes place at water temperatures between $5^{\circ} \mathrm{C}$ and $10^{\circ} \mathrm{C}$ (Scott and Hubert et al. 1985, Crossman 1985, Nelson and Paetz 1992, Joint and Sullivan 2003), which is usually the end of April or beginning of May in Alberta, although some populations may spawn as late as the beginning of June (Joint and Sullivan 2003). Males will arrive first in small tributaries and set up territories that they defend from other males. Males use their large brilliantly coloured dorsal fins to display threats and gape with their mouths to warn other males off their territories (Joint and Sullivan 2003). Neither males nor females dig redds (excavations for fish eggs dug into the gravel) like some other species in the trout family (Scott and Crossman 1985; Behnke 2002), although grayling may sweep the substrates with their tails during the spawning act (M. Sullivan, pers. comm.). Females remain separate from males until ready to spawn. When a female enters a selected male's territory, the male uses his dorsal fin to clasp the female beside him during spawning (Nelson and Paetz 1992). The pair entwine themselves and vibrate together, which stimulates the female to release eggs and the male to release sperm for fertilization. The male fertilizes the eggs as they drop into the water and the eggs become entrained within the loose gravel below.

In these areas the slightly adhesive eggs lodge in the gravel interstices where they will incubate. Females spawn between 5000 and 6000 eggs per $0.5 \mathrm{~kg}$ of body weight; this is considerably more than most trout and salmon, which produce between 800 and 1000 eggs per $0.5 \mathrm{~kg}$ of body weight (Behnke 2002). Grayling invest less energy on a per-egg basis in order to produce 
more eggs per adult; this may be a trade-off adaptation to offset reduced spawning success because of highly variable spring conditions.

The embryos develop rapidly, with hatching occurring after about 15 days incubation (Behnke 2002), at temperatures of between $7^{\circ} \mathrm{C}$ and $11^{\circ} \mathrm{C}$ (Berry 1998). This development is much more rapid than is required for trout and salmon (Behnke 2002). After hatching in the gravel, grayling fry are supported by their yolk sac. After about 8 days, they swim up to the water surface and drift to slow-moving creek margins and backwaters. Young-of-year often remain in natal streams for one-and-a-half years before moving downstream into larger streams (Berry 1998). After spawning in the tributaries, adults will most often leave the tributaries and move downstream.

It is not known how much fidelity Arctic grayling have to spawn in natal streams. Trapping evidence suggests that spawning streams are used annually, but in years of low flows or inaccessibility from beaver dams, grayling may select alternate streams in a watershed for spawning (Berry 1998).

\section{Growth, Maturity and Age-specific Mortality}

- Although a comprehensive examination of growth across the province has not been carried out, growth rates appear to be similar (Berry 1998). Exceptional in this regard are populations in northeastern Alberta, which have faster growth (Sullivan 1988), and populations in northwestern Alberta that may have slightly slower growth for young fish (T. Ripley, pers. comm.). In general, Alberta grayling grow quickly, which is likely an evolutionary adaptation that works in conjunction with early age-at-maturity to avoid predation and perhaps a response to marginal habitat conditions along the southern edge of the Alberta range (D. Park, pers. comm.). Fast-growing grayling reach $20 \mathrm{~cm}$ (total length) in their second to third year (Figure 1). Growth rates slow thereafter, as

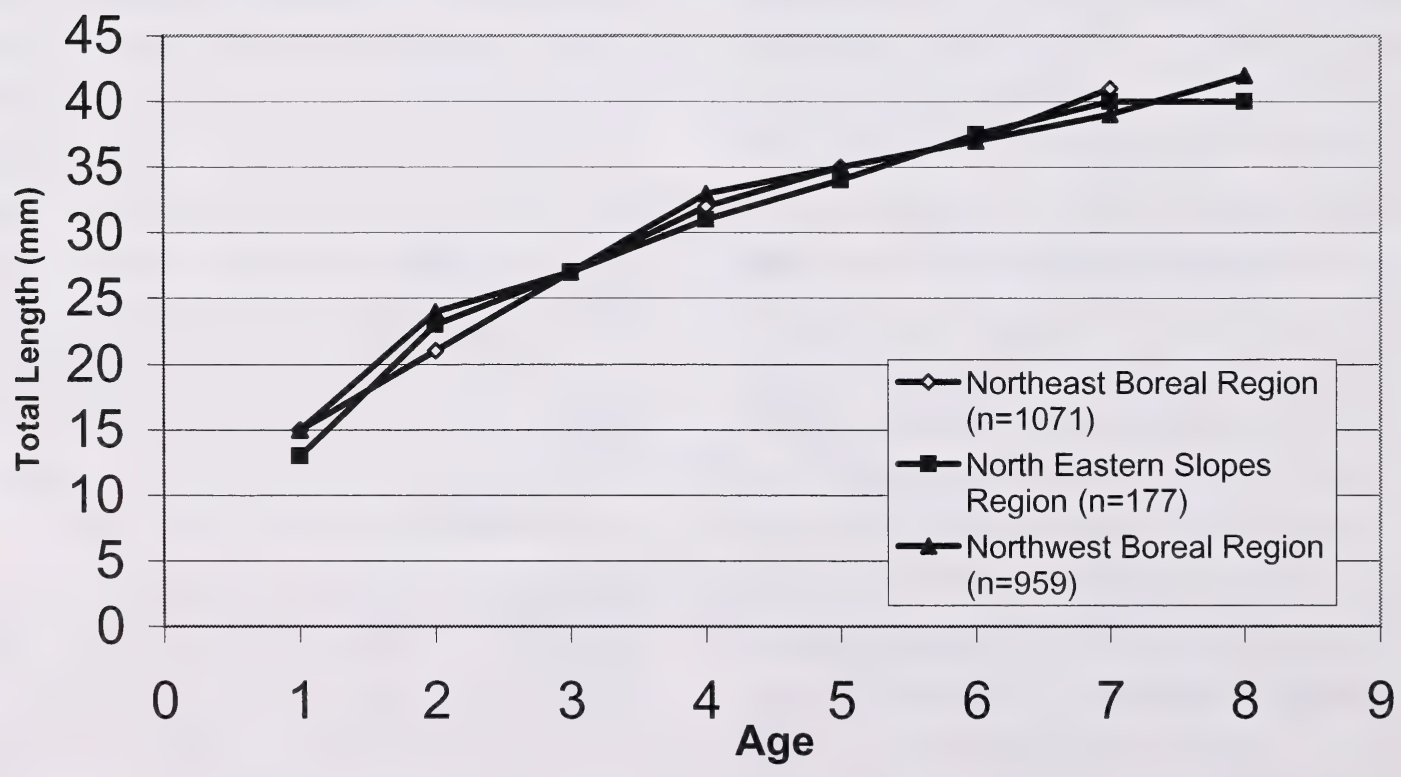

Figure 1. Length-at-age relationship for Arctic grayling from three composite samples from three provincial management areas in Alberta. These data are adapted from Berry (1998). 
energy is switched from somatic to reproductive growth, so that a grayling reaches $35 \mathrm{~cm}$ (total length) at approximately five to six years of age. This $35 \mathrm{~cm}$ is the current angling minimum size limit in Alberta for some water bodies. It is designed to allow the individual grayling the chance to reach maturity before becoming available to angler harvest (Berry 1998). On average for Alberta, a few grayling mature in their second year, $50 \%$ are mature at age three, and nearly $100 \%$ are mature at age four (Berry 1998). However, an analysis of populations in northwest Alberta showed a slower maturity schedule with $58 \%$ mature at age four and $100 \%$ maturity at age $8(n=2109$, T. Ripley, unpublished data). It is not known whether grayling in Alberta show any density-dependent response for sizes or ages at maturity.

Most populations in Alberta do not contain fish older than six or seven years of age. From 34 age distributions collected from 1947 to 1996, only the Kakwa River population had ages greater than 9 years (Berry 1998). From the Kakwa River, (a low to moderately exploited population with good habitat conditions), 1 of 132 sampled fish reached age 12 (Ripley 1998). From a catch curve analysis of grayling from the Kakwa River the total annual mortality was 0.51 (total annual survival $=0.49)(\mathrm{F}=0.0019$, $\mathrm{R} 2=0.93, \mathrm{df}=5$ ). Age distributions from unexploited populations in Alberta do not exist to separate the total annual mortality from the Kakwa into its component parts of "fishing" and "natural" mortality using the unexploited rates of mortality as a baseline.

\section{DISTRIBUTION}

\section{Alberta}

Preface - The estimated extent of occurrence for grayling in Alberta is $403000 \mathrm{~km}^{2}$, which is approximately $6 \%$ of their North American range. To determine this proportion, the distribution for grayling provided by McPhail and Lindsey (1970) was used. This area should be used only as a rough guideline because it is dominated by land features and includes all lakes and streams, not just those that have grayling. The actual area of water that contains grayling is unknown.

A summary of occurrence and abundance information is included in the following paragraphs. These data have been collected for a variety of purposes over many decades and the methods, timing and extent of data collections have changed depending upon the researcher and the purpose of the collections. The consistently collected, quantifiable monitoring data upon which to make an assessment about the number of fragmented populations, the extent of the fragmentation, definitive trends in specific populations or the magnitude of annual variations in populations does not exist. Because of the nature of the existing abundance data, there is room for interpretation. There are no specific guidelines for key population parameters that have been established to indicate the relative size, stock status or risk for that population.

Populations of grayling in Alberta occupy three major watersheds from north to south: Hay River, Peace River, and Athabasca River (Figure 2 ). Within these drainages, genetic studies have not yet been conducted to determine the number of populations, or the extent of similarity between populations in Alberta. Grayling occur within the Fisheries Management watershed units NB1, NB2, NB3, NB4, ES4 and ES3 (Figure 2). With the exception of a small population in the Belly River, the southern limit of grayling distribution in Alberta is in the Athabasca River drainage, and more specifically tributaries to the Pembina River.

Provincially, declines in abundance of grayling occurred primarily in the 1950 s to 1970 s and resulted in declines of over $90 \%$ for approximately $50 \%$ of subpopulations in Alberta (Appendix 2) (Sullivan 2005). Many of these remnant populations remain at too low a density to support fisheries or play a role in community dynamics (Sullivan 2005). This range contraction by effectively extirpated populations 


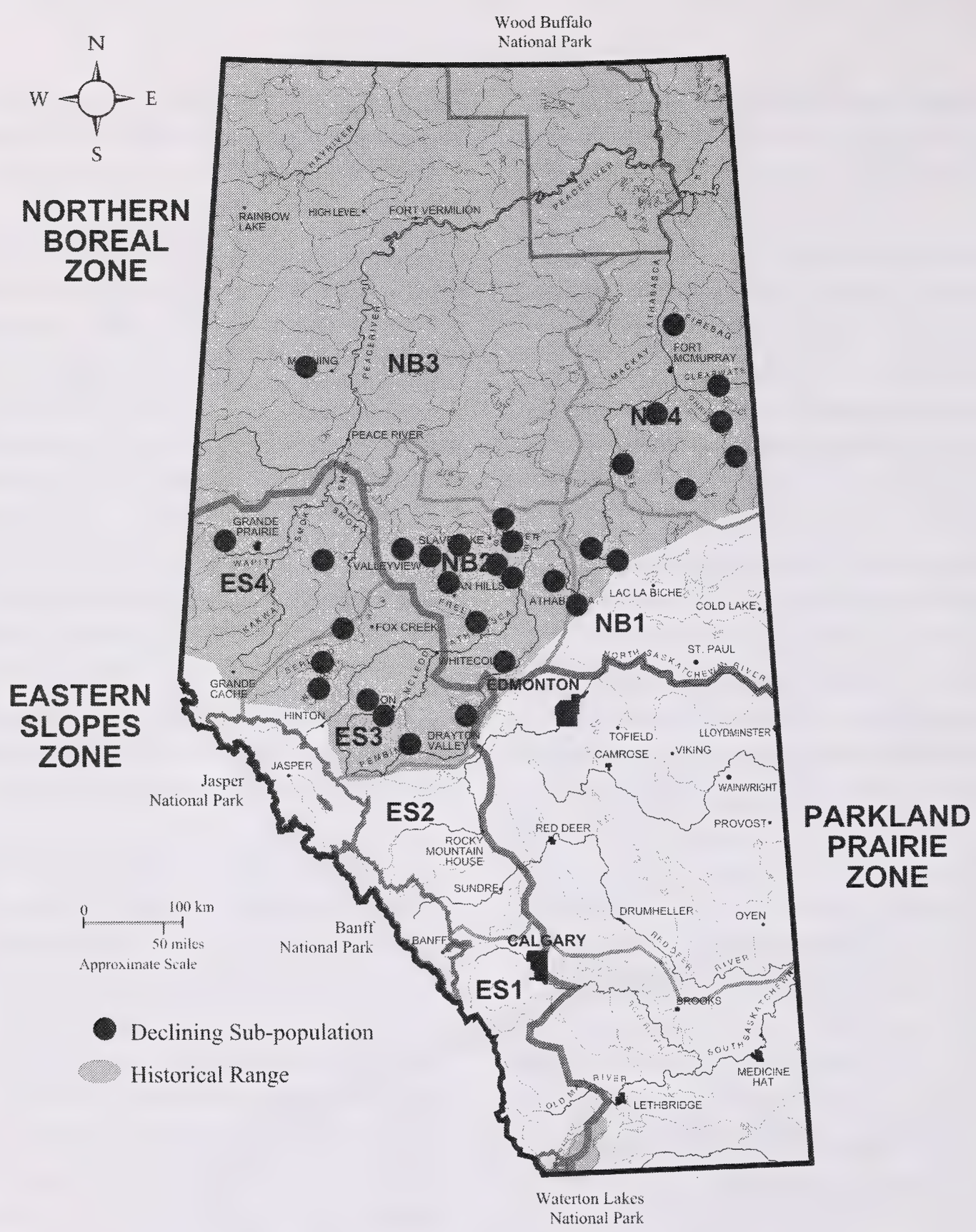

Figure 2. Estimated current and historical distribution of Arctic grayling in Alberta. Grayling are found naturally in the Hay, Peace and Athabasca river drainages and in Provincial Watershed Units NB2, NB3, NB4, ES3, NB1 and NB4. The Belly River population, in southern Alberta, is believed to be exotic (NatureServe 2004, T. Clayton pers. comm.), but may be part of the historical disjunct population of native Arctic grayling in the Upper Missouri drainage. The historical distribution (in grey) is based upon information contained in Scott and Crossman (1985), Nelson and Paetz (1992), Joint and Sullivan (2003), Bryski (1997a, 1997b, 1998, 1999a, 1999b), Stanislawki (1998, 1999), Stanislawski and Brown (1996), Ripley (2003), Valastin and Sullivan (1997), and Berry (1998), as well as the many references cited in this report. The black dots are subpopulations that show probable declines from pre-settlement conditions from Sullivan (2005). They represent an estimated $40 \%$ decline from the original range. 
is estimated to represent $40 \%$ of the historical range (Figure 2)(Sullivan 2005). Some populations may have also been extirpated such as Tawatina River, tributaries to Baptiste Lake, Calling River, and tributaries near Whitecourt of the McLeod River. It is important to note, however, that sampling effort may be too low to detect rare fish.

Along the southern boundary of the species' range in Alberta (Pembina area), grayling are likely naturally vulnerable to range contraction. This vulnerability may also be the case for grayling populations in foothills streams with low latitudes and elevations or boreal streams with low latitude, low gradients or low elevations (J. O'Neil, pers. comm.); however, no specific studies have been conducted to date in Alberta to illustrate this. In general, grayling throughout Alberta live in an environment of high environmental variability (summer temperatures, water levels, gradients, winter conditions). More extreme conditions, particularly along the southern edge, may make these populations more vulnerable to range contractions. When compared with other species of game fish in Alberta that occupy more stable environments (lakes, larger rivers), grayling may have biologically compensated for natural limiting factors by having faster growth rates and early maturity. This is difficult to know for certain because there has not been a comprehensive look at grayling maturity or growth along a gradient of habitat types or locations. For populations in Alberta along the southern range and those at low altitudes and low gradients from across Alberta, these populations may have higher natural mortality, which may make them more susceptible to declines as a result of human activities. It is likely that at the southern edge of their range, grayling can afford little additional mortality arising from habitat fragmentation (culverts and roads), increases in temperature (land-use changes, climate change), and angling pressure. It is probable that the cumulative nature of these anthropomorphic factors is changing the distribution of grayling, particularly along the southern limit of their range. Many populations in the Pembina, McLeod, Berland, Lesser Slave, Christina, House, Clearwater, Jackfish, Swan and Smoky rivers are "all but lost" (Berry 1998), having had healthy populations until the 1950s.

There is also a very small, disjunct population of grayling in the Belly River near the southwestern border of Alberta and the United States. These fish may be a result of stocking from Elizabeth Lake in 1924 and 1962 in Glacier National Park by United States managers ( $T$. Clayton, pers. comm.). The Elizabeth Lake population is believed to be self-reproducing. According to Glacier National Park records, grayling did not appear in the Belly River before lake stocking (T. Clayton, pers. comm.). The stock from which this population is to have come is unknown. The Belly River drains Elizabeth Lake, and an unknown, but presumably very small, number of grayling inhabits the Belly River. Dawn Mist Falls is located $6 \mathrm{~km}$ downstream of Elizabeth Lake on the Belly River, and acts as an upstream barrier over which the grayling must descend. It is considered rare for an angler to catch a grayling in the Belly River, and an electrofishing survey in 1999 from the U.S. border to the Belly River weir (160 minutes of electrofishing) did not capture any grayling. One grayling is listed in the Fisheries Management Information System (FMIS) from August 6, 1999, having been angled at the Belly River campground in Waterton Lakes National Park (T. Clayton, pers. comm.). The Belly River has two tributaries: the Mokwanis River and the North Belly River. No grayling have been captured in the North Belly, and the Mokwanis has impassable falls two $\mathrm{km}$ from its confluence with the Belly River.

A few populations of grayling occur naturally in small lakes in northern Alberta such as Freeman Lake (Berry 1998) and Legend Lake (D. Park, pers. comm.).

Subalpine lakes, Bear Pond and Big Iron Lake in the upper Oldman drainage have previously been stocked (Nelson and Paetz 1992) as well 
as Quarry Lake, Wedge Pond, Sparrow's Egg Lake, and Champion Lakes in southern Alberta (J. Stelfox, pers. comm.). Grizzly Lake north of Edson (D. Park, pers. comm. and C. Hunt, pers. comm.) and Peace Pond (T. Ripley, pers. comm.) west of Peace River have also been stocked. There is no evidence of survival at Sparrow's Egg Lake and Champion Lake. Some evidence of natural recruitment has been observed at Bear Pond, Big Iron Lake and Quarry Lake (J. Stelfox, pers. comm.).

Grayling do not occupy Jasper National Park naturally (W. Hughson, pers. comm.), although they were stocked occasionally in Lac Beauvert, Buck Lake, Edna Lake, Iris Lake, Katrine Lake, Moab Lake, Osprey Lake, Palisade Lake, and Vine Creek Dam between 1954 and 1969 (W. Hughson, pers. comm.). These stocked water bodies do not contain grayling today (W. Hughson, pers. comm.)

\section{Other Areas}

Arctic grayling have a Holarctic distribution ranging from streams in Mongolia across northern Eurasia and North America (Scott and Crossman 1985, Behnke 2002). Within North America, grayling occupy drainages from Hudson Bay to Alaska, including the Northwest Territories, Yukon, and Nunavut, as well as northern areas of British Columbia, Alberta, Saskatchewan and Manitoba (Figure 3). Populations that existed in rivers flowing into Lake Michigan, Lake Huron and lakes in northern Michigan are now extirpated (NatureServe 2004). Populations in Montana are maintained through catch-and-release regulations and an active hatchery-stocking program (Behnke 2002). Grayling have been introduced into California, Arizona and Nevada.

\section{POPULATION SIZE AND TRENDS}

\section{Alberta}

General

Sullivan (2005) estimated that $50 \%$ of subpopulations of grayling declined up to $90 \%$ in abundance in the 1950s to 1970s (Appendix 2). The declines were severe resulting in remnant populations that no longer function in aquatic community dynamics and were effectively extirpated (Sullivan 2005). In some cases populations may have been wholly extirpated (Tawatina River, tributaries to Baptiste Lake, Calling River, tributaries of the McLeod River near Whitecourt), but sampling effort may also have been too low to detect these rare fish.

Consistently monitored trend data for relative abundance within a watershed do not exist for most populations in Alberta. An exception to this may be data from the upper reaches of the Little Smoky River (tributary to the Smoky and Peace rivers), where angler catch rates, relative abundance and length distributions have been monitored in 1988, 1992, 1994 and 1997 (Alberta Sustainable Resource Development file data, Edson).

With the exception of a mark-recapture population estimate for grayling in the Kakwa River (Ripley 1998), populations have been surveyed or monitored using indices such as electrofishing, angling catch rates, as well as age and length distributions. Trapping during spawning has also provided relative measures of stock size.

Five projects summarize population status and trends for different areas in Alberta. Berry (1998) provides provincial summary data in Alberta's Arctic Grayling Management and Recovery Plan. The Alberta Conservation Association (Bryski 1997a, Bryski 1997b, Bryski 1998, Bryski 1999a, Bryski 1999b) has developed summary reports of interviews and regional Fish and Wildlife data compiled to 1997 for the upper Athabasca and Smoky river watersheds. Extensive field surveys have been conducted from 1996 to 2003 and summarized for the Lower Athabasca watershed in the Alberta Pacific Forest Industries Inc. (ALPAC) forest management area (Stanislawski and Brown 1996, Stanislawski 1998, Stanislawski 1999). Ripley (2003) reviewed regulations and 


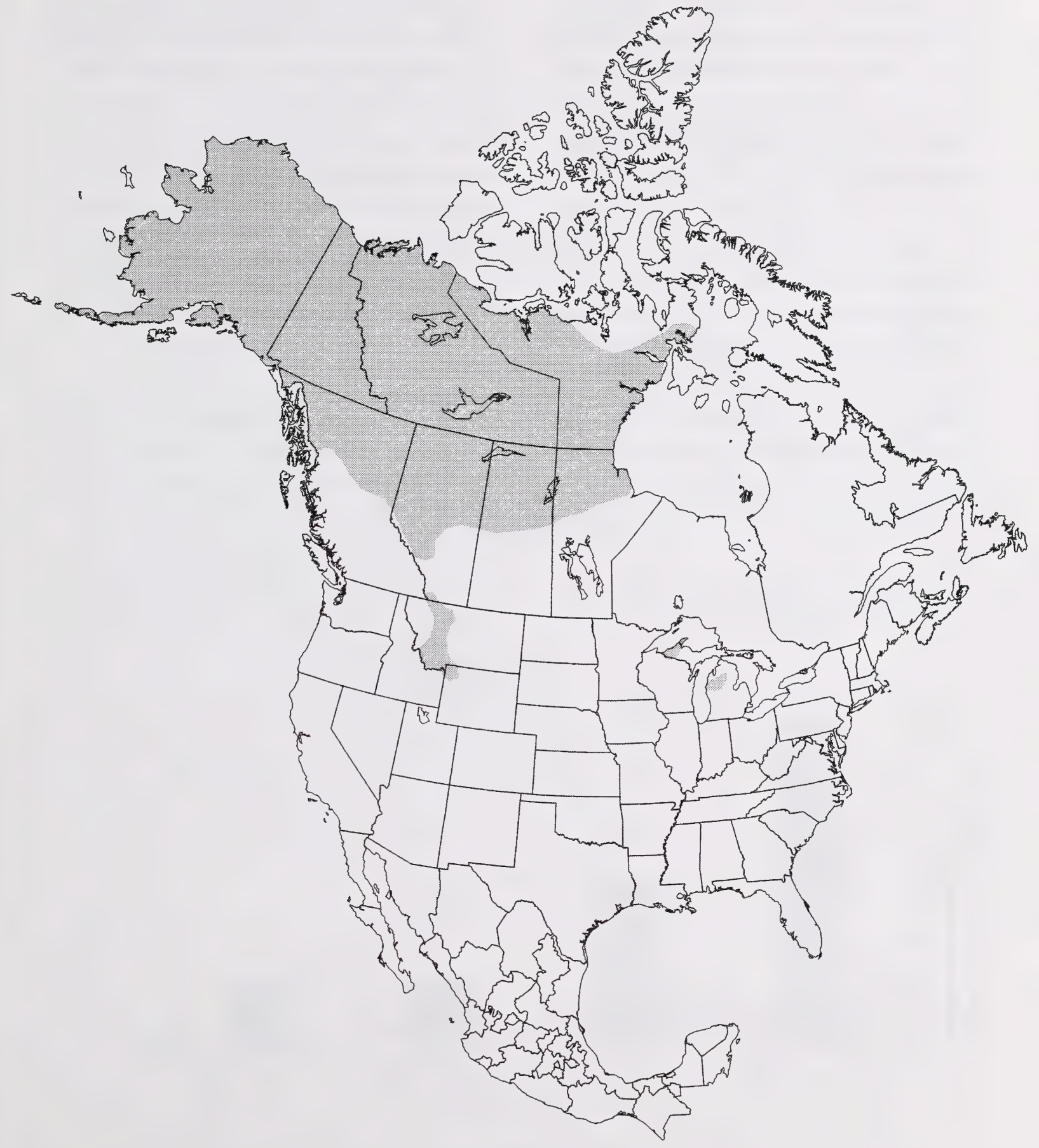

Figure 3. Distribution of Arctic grayling in North America. The two populations in the eastern United States are presumed extirpated (NatureServe 2004). 
summarized and compared unpublished Fish and Wildlife Division and Alberta Conservation Association population data in four zones in the Peace River watershed and a small part of the Athabasca watershed (Lesser Slave area). Sullivan (1988) summarized occurrence, growth and maturity data for northeastern Alberta populations.

For all populations, very few data from prior to the 1970s exist, making temporal comparisons difficult. For accessible populations of grayling, many had apparently already declined by the time biologists began to study them. Historical accounts compiled from angler reports, early explorers' journals, as well as interviews and photographs from retired biologists and fish and wildlife officers have given managers a qualitative picture of what some grayling populations may have been like before they declined (Valastin and Sullivan 1997, Bryski 1997a, Bryski 1997b, Bryski 1998, Bryski 1999a, Bryski 1999b).

Northwestern Alberta - Provincial Watershed Units NB2, NB3 and ES4.

Recent field surveys (within the last eight years) of Arctic grayling have been conducted predominantly in the remote Caribou Mountains area, Notikewin/Hotchkiss area, Lesser Slave Lake area, and an area south of Grande Prairie (Ripley 2003).

Populations in the Caribou Mountain area have relatively high densities (Figure 4), with large fish being well represented. Within the Caribou

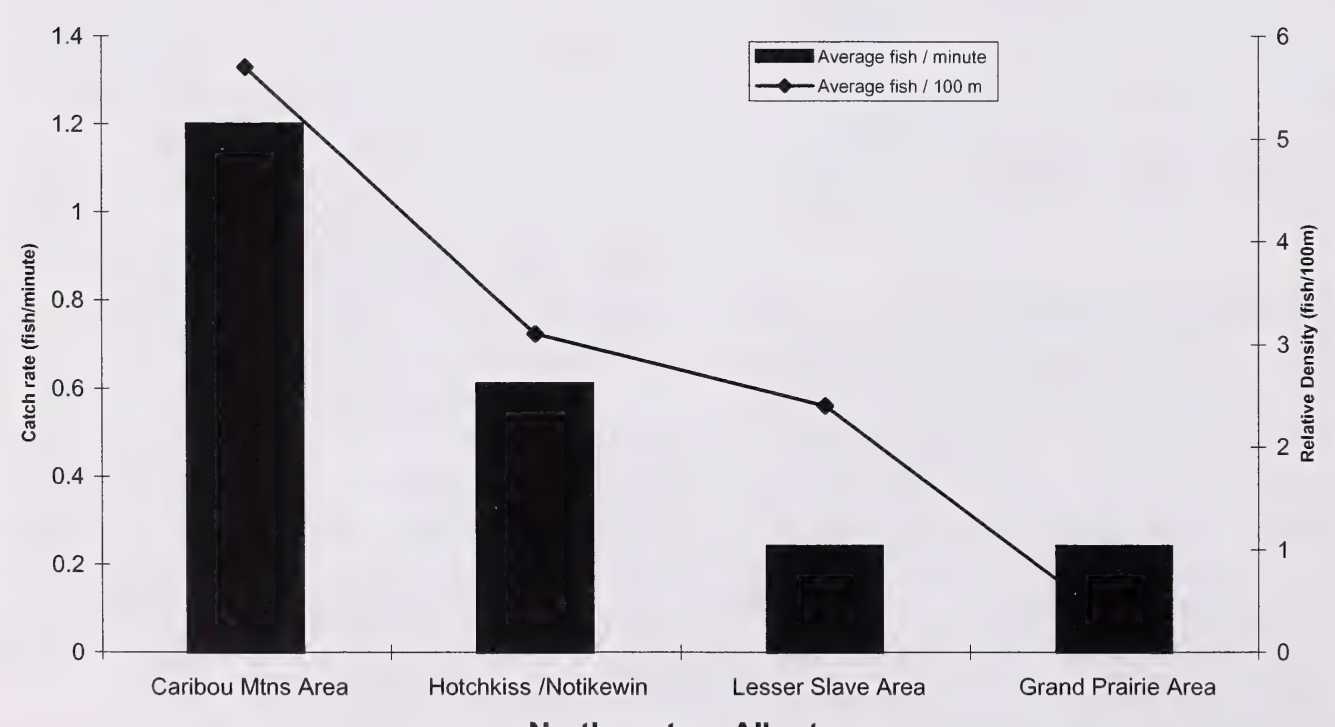

Northwestern Alberta

Figure 4. Electrofishing catch rate (grayling per minute) and relative density (grayling per $100 \mathrm{~m}$ ) for grayling in northwestern Alberta (Ripley 2003). 
Mountains, 32 sites were sampled, with an overall electrofishing catch rate of 1.2 fish per minute and an average density of 5.7 grayling per $100 \mathrm{~m}$ of stream electrofishing. These high densities are indicative of populations in remote areas with little habitat fragmentation and road development. Of the 775 fish measured, $13.8 \%$ had total lengths greater than $35 \mathrm{~cm}$ (the 2004 provincial angling minimum size limit-a minimum size limit is the total length in centimetres that a fish must reach before an angler may keep the fish as part of his bag limit). These higher densities are probably a result of low angling exploitation and low habitat fragmentation because of lower road development, combined with good habitat conditions (moderate gradient boreal system).

The Notikewin/Hotchkiss area had a moderate fish density and catch rates that were less than the Caribou Mountains (Figure 4). Of 102 sites surveyed, average electrofishing catch rates of 0.61 grayling per minute and 3.1 grayling per $100 \mathrm{~m}$ of stream were recorded.
In the tributaries south and east of Lesser Slave Lake, the average catch rates of grayling were 0.24 grayling per minute, with an average density of 2.4 grayling per $100 \mathrm{~m}$ (Figure 4).

The area south of Grande Prairie had the lowest density in the Fish Management Zone (Figure 4). The average catch rates were 0.24 grayling per minute of electrofishing and 0.29 fish per $100 \mathrm{~m}$.

Of the 36 drainages sampled in the Northwest Boreal Region, $11 \%(n=5)$ had electrofishing catch rates greater than 1 fish per minute (Figure 5), and densities of greater than 4 fish per $100 \mathrm{~m}$ of electrofishing. The Keg River supported the highest densities in the region, nearly 16 fish per $100 \mathrm{~m}$ of electrofishing and 4 fish per minute. Angling catch rates were not determined in this survey, and the extent of angler exploitation is not known.

The Kakwa River has low but increasing watershed development and the habitat is

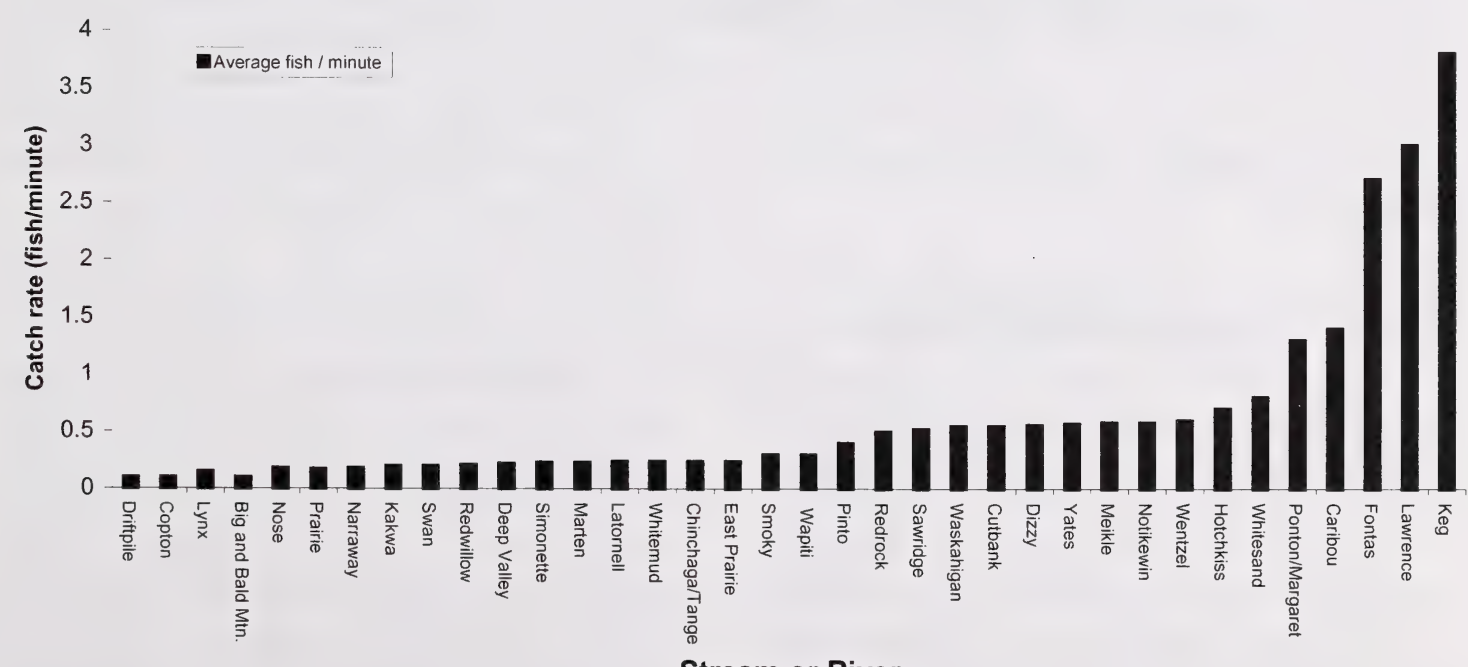

Stream or River

Figure 5. Electrofishing catch rates of Arctic grayling from surveys conducted in northwestern Alberta (Ripley 2003). 
considered "pristine" by regional fishery personnel (from the perspective of grayling management) (Ripley 1998). Because of its relatively difficult (but increasing) access, exploitation from angling has been considered to be relatively low, but information on angler effort and harvest is not available. In 1997, using mark-recapture techniques, an estimated population of 482 (95\% CI, 415-550) grayling were occupying a $32-\mathrm{km}$ reach of the Kakwa River (Ripley 1998). This corresponded to 15.1 grayling per river kilometre, an electrofishing catch rate of 0.31 grayling per minute (18.6 grayling per hour), and an angling catch rate of 1.2 grayling per hour. The majority of fish in the sample were ages 5 and 6 , with fish up to age 11 represented in the sample. The mean fork length of grayling in the measured sample $(n=392)$ was $294 \mathrm{~mm}$ (318 $\mathrm{mm}$ total length).

The Little Smoky River also provides reference data for lightly exploited populations with low watershed development (Figure 6). This highdensity catch-and-release population was surveyed in 1988, 1992, 1994 and 1997, and the data illustrated the large variation in recruitment that this population undergoes, as well as how much grayling can grow if harvest pressure remains low. Angling catch rates have varied between 2.4 and 6.8 fish per hour and the proportion of the samples greater than the provincial angling size limit has ranged from $16 \%$ to $54 \%$.

When trying to understand the characteristics of a lightly exploited population, biologists must consider carefully the extent of the variation that these populations naturally undergo. The concept of a theoretical carrying capacity must include this naturally high environmental variation to which these populations are adapted. These Little Smoky River data illustrate this high variation. These data also suggest that grayling populations may only support a small amount of angling or watershed development because they naturally have periods of lower density where they might be susceptible to overharvest or watershed development.
The Wapiti River and tributaries were examined in 2000 to document seasonal movements, spawning site selection and population composition of Arctic grayling. Trapping results on the Redwillow River indicate a total of 217 grayling ranging in size from 267 to $406 \mathrm{~mm}$ fork length $($ mean $=330 \mathrm{~mm})$. All fish captured were sexually mature, ranging from 4 to 10 years of age. During the 2000 and 2001 studies, Arctic grayling spawning locations showed a strong preference for two sites in the Redwillow River, each approximately $5 \mathrm{~km}$ in length.

\section{East Slopes Alberta - Provincial Watershed Unit ES3}

With the exception of grayling in the upper Little Smoky River, many populations within these east-slopes watersheds have declined and are extremely small when compared to historical levels described in anecdotal reports.

Bryski (1998) summarized the available abundance information by major watershed for grayling up to 1997 (Appendices 3, 4, 5 and 6) and reported historical interviews with local anglers. Although it is difficult to quantitatively compare these abundance measures because of the varying techniques and sampling efforts, certain conclusions could be drawn. Within the McLeod River watershed, interviewees often reported historically good to excellent catches of grayling from the McLeod River and many of its tributaries, with declines being noted in the fisheries in the 1950s-1970s. Based upon interviews, professional opinion and available biological information, Bryski (1999a) concluded that populations in the McLeod River and its tributaries-Shiningbank Creek, Carrot Creek, Edson River, Moose Creek, Schwartz Creek, Embarras River, Erith River, White Creek, Gregg River and Sundance Creek-had declined significantly from the pre-1950s to the 1990s. From a composite sample (1980s to 1997) from the McLeod watershed, no fish was observed to be older than five years of age, and $34 \%$ of the fish were older than one year of age (Figure 7, Bryski 1999a). 


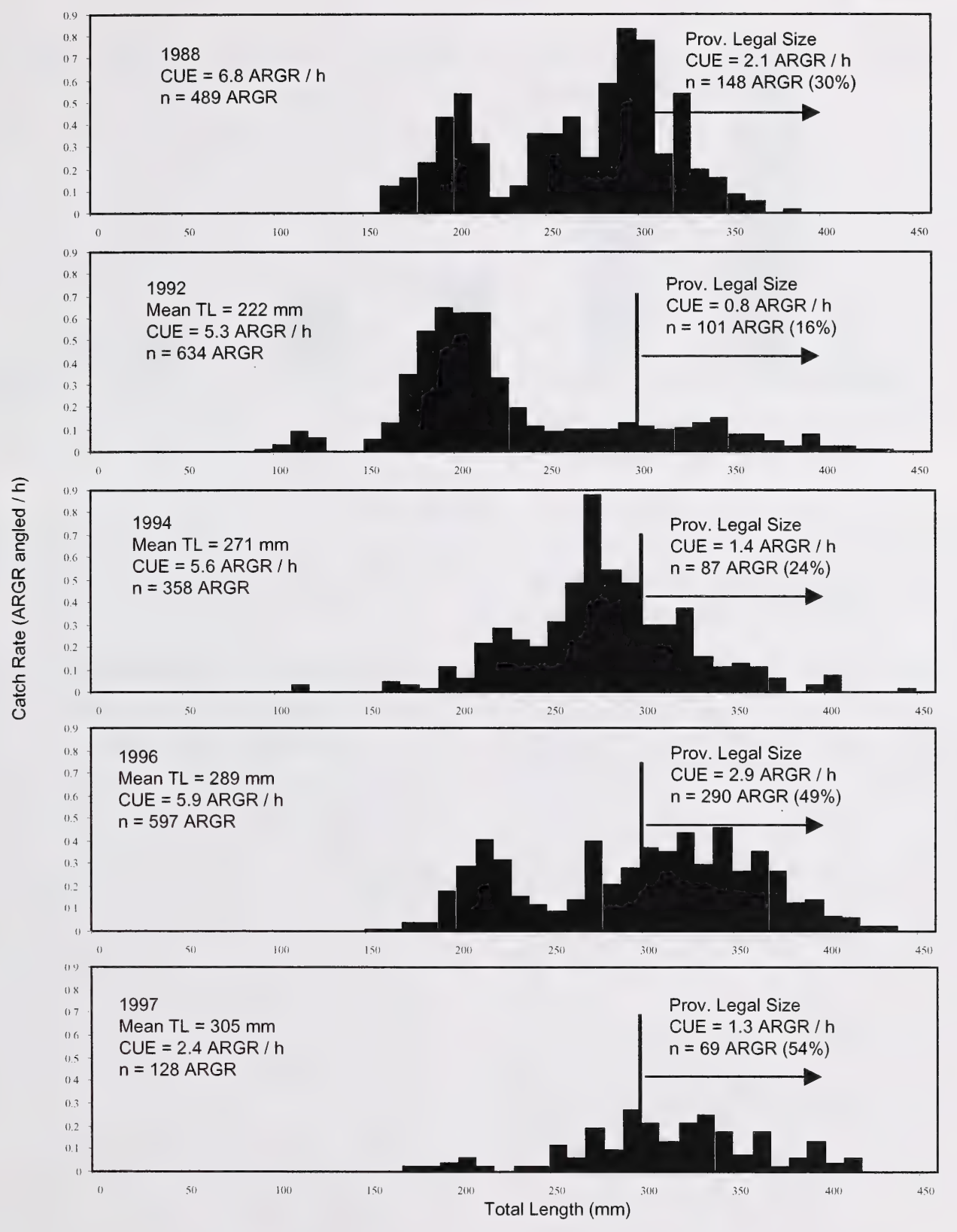

Figure 6. Total length frequency distributions $(\mathrm{mm})$ for Arctic grayling angled from the Little Smoky River, 1988-1997 (M. Sullivan, unpubl. data). (TL = total length, CUE = catch per unit effort, ARGR $=$ Arctic grayling). 


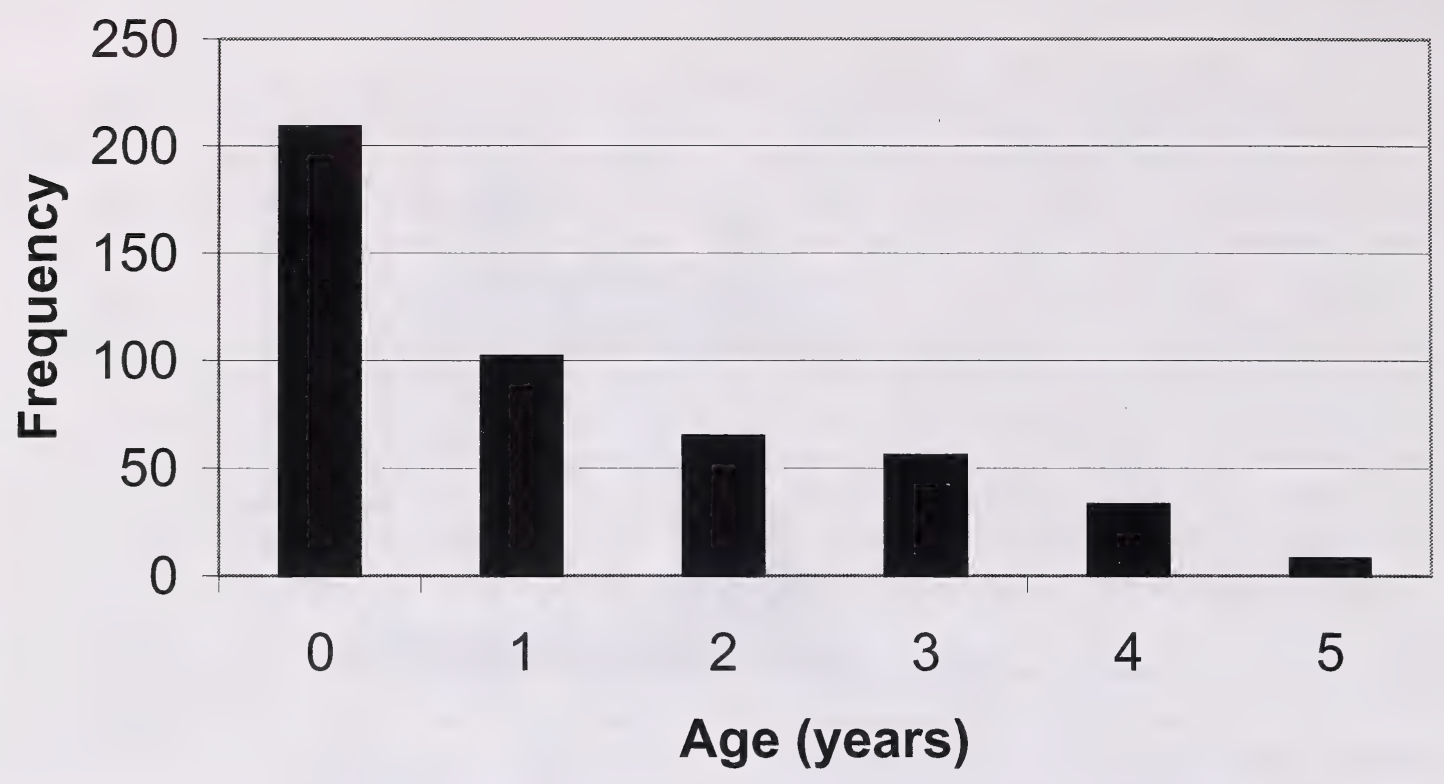

Figure 7. Age distribution of a composite grayling sample from the northeast slopes reported in Bryski (1999a) for the McLeod River drainage.

As a more specific example from the McLeod River watershed, Sundance Creek was once considered to be one of the best grayling fisheries west of Edmonton. The earliest report of grayling in the creek comes from Walter Cheadle's journal in 1863 , in which he remarked upon the most excellent fishing (Cheadle 1971). Interviews with two avid fishermen, George Mitchell and Charlie Peet, refer to large numbers of Arctic grayling in the creek in the 1930s and 1940s, where they recall well-worn paths to pools from anglers (Bryski 1999a). Miller and Macdonald (1949) described the population as "splendid" in the upper reaches of the creek, but suggested that angling pressure in the lower reaches had made grayling "shy." Anglers reported catch rates of up to 20 per day and being able to catch their limits from the 1950 s to the 1980 s, although sizes of the fish were small unless you fished the headwaters. Snyder (1971) indicated good grayling fishing in the upper reaches. By the 1990 s the population had collapsed, and extensive spring trapping and electrofishing showed very low catch rates and the absence of a well-defined spawning population (R.L.\&L. 1995a, 1995b). An angling survey revealed that 20 volunteer anglers in 1996 caught 2 grayling in 48.5 hours of effort from highway 16 to
Sundance Lake (Johnson and Walker 1997). They concluded that while grayling may still be present, the population was at a very low density.

Generally, within the Pembina watershed, contemporary sampling of grayling populations has indicated very low densities of grayling (Appendix 4), if any are encountered at all. Of those that are captured, the majority are young and immature fish located often in the smaller tributaries of the watershed (M. Blackburn, pers. comm.). In the spring and summer of 1998 , in tributaries to Dismal Creek, 54 grayling were captured during 12 electrofishing surveys $(\mathrm{K}$. Gardiner, pers. comm.). In an additional six surveys conducted in 2000 , nine grayling were encountered. In the summer of 2003, electrofishing in the Pembina River, including the junctions of Nelson Creek, Dismal Creek, Rat Creek, Paddy Creek and the Bigoray River, four grayling were caught by electrofishing and seven were angled (C. Johnson, pers. comm.). Road densities in this area are "unbelievably high" and "among the highest we've ever encountered" (C. Johnson, pers. comm.).

Historically, many of these tributaries have offered good fishing for Arctic grayling, with 
larger fish having been reported. Bryski (1999b) summarizes angler reports of "pail-fulls" of grayling in the small creeks west of Chip Lake in the early $20^{\text {th }}$ century. By the 1960 s he reports that anglers generally spoke of good grayling fishing in the past tense, although grayling were still present (Cunningham 1961; ARDA 1970). Cold Creek in the 1940s to 1950s was reported by Martin Paetz, Clare Stone and Doug Markley to be good, with 5-10 grayling caught in an afternoon of fishing (Bryski 1999b). Ward (1951) documented a spawning population in Cold Creek of several hundred grayling with fish up to $326 \mathrm{~mm}$ fork length (age 7) in the sample.

Fishing in the Bigoray River was reported to be excellent by Thomas (1956), but Cunningham (1961) describes grayling as "possibly present in small numbers." Paddy and Rat creeks were both reported to have good fishing, with fish up to $35 \mathrm{~cm}$ (Martin Paetz, George Mitchell, in Bryski 1999b). Cunningham (1961) characterized Rat Creek as one of the best fisheries in Alberta at one time, but by 1960 he only found a few small grayling. Studies of Rat Creek in 1995 showed a very low density, young population of grayling with few mature fish present (O'Neil and Patalas 1995). It should be noted that the Rat Creek population appeared to be restricted to a short section of good habitat (J. O'Neil, pers. comm.). Only a very few fish have been encountered in this area in recent electrofishing surveys (C. Johnson, pers. comm.).

In conclusion, Bryski (1999b) reports that the grayling populations in Bigoray River, Paddy Creek, Rat Creek, Dismal Creek, and Zeta Creek have all declined. One of his interviews with long-time anglers noted that it was no longer worth the time to fish these streams, even though it required less effort today to access the streams than it did in the 1960s.

Very few data on the abundance of grayling in the Berland River watershed are available. However, in interviews conducted in 1997 (Bryski 1997b), many anglers reported excellent catch rates and sizes of fish in the 1950 s to 1970 s. One angler reported catches of 20-30 fish per day in the 1960s and 1970s. Another talked of catching 5-6 per pool in the vicinity of the Berland Forestry Fire Tower. Others reported catching limits of grayling of $35 \mathrm{~cm}$. Most agreed that populations had definitely declined. In a short creel survey in October 1981, Hawryluk (1981) reported a catch-rate of 4.7 grayling per hour by anglers. A one-day creel survey of the same area in 1992 reported a catch rate of 0.1 grayling per hour. In an electrofishing survey, Earle (1996) reported very low catch rates of grayling (0.6-6 grayling per hour).

Fishing has been reported by anglers to be good in the past in the Wildhay River and tributaries (Bryski 1999a.). Studies conducted in 1992 (R.L.\&L. 1993) reported very low electrofishing catch rates of $0.04-0.73$ fish per hour. Tributary electrofishing sampling in July 1996 by the Foothills Model Forest suggested low population abundance for grayling in Hightower and Pinto creeks (Johnson 1996). Two grayling were captured in 1088 seconds of electrofishing in Hightower Creek $($ CPUE $=0.002 \mathrm{fish} / \mathrm{sec})$. No grayling were captured in Pinto Creek in 2178 seconds of electrofishing. Cunningham (1960) had previously described Pinto Creek as having plentiful grayling.

Northeastern Alberta - Provincial Watershed Units NB1 and NB4

In this area of the province, extensive sampling for Arctic grayling has been undertaken in the ALPAC forest management area (Stanislawski and Brown 1996, Stanislawski 1998). The results of these angling surveys indicate that densities of Arctic grayling are highest in the low-access Ells River ( 8 grayling angled/hour) and lowest in the highly accessible House (1.2 grayling angled /hour) and Gregoire (1.1 grayling angled/ hour) rivers (Figure 8 ). With the exception of the Ells River, most of these populations appear to be low density, with catch rates of less than 4 grayling per hour. Generally, populations of grayling in this area are composed of young, smaller fish. There are few historical population 


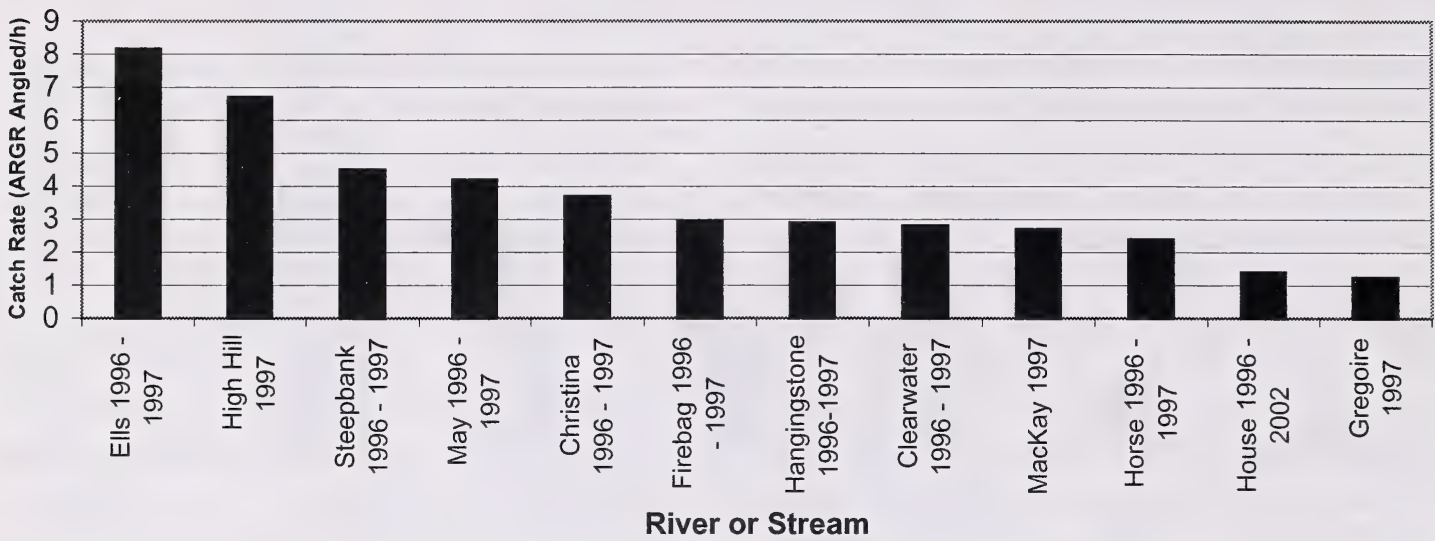

Figure 8. Average catch rates (Arctic grayling angled per hour) for 12 drainages and their tributaries in the North East Boreal region sampled in 1996 and 1997 (Stanislawski and Brown 1996, Stanislawski 1998).

data available to assess the trend in abundance over time. However, angler reports and interviews indicate that the catch of grayling in the 1940s-1970s was much higher than it is today for some of these drainages (Valastin and Sullivan 1997, Fish and Wildlife Division file data). John Doonanco (retired Fish and Wildlife officer) reported significant declines in the catch rates and sizes of grayling in the Christina and Jackfish rivers by the 1980s (letter to Fish and Wildlife; Doonanco 1991). When interviewed, long-time resident Mike Maskalyk related that "it was good grayling fishing at the railroad bridge on the Christina River," and that "before the road to Fort McMurray, hundreds of grayling would go for your hook at the House River rapids." He recalls catching grayling up to 18 in. ( 40 cm) (Valastin and Sullivan 1997).

Martin Paetz recalled that at the railroad crossing on the Christina River, the train crew fished for Arctic grayling and that there were a lot of grayling. He remembered that the crew "would pickle them like herring." In 1967, he filmed the Alberta portion of "The Canadian Fisherman" (CBC) and remembered catching 33 grayling (all longer than 12 in. [ 36 cm]) in the Christina River in less than an hour. In 1987, M. Paetz and John Doonanco returned to the same place and fished hard for two days and caught seven grayling in total, of which only one was greater than 12 in. $(\sim 30 \mathrm{~cm})$ (Valastin and Sullivan 1997). Stanislawski (1998) caught nearly 4 fish/ hour in the Christina River with an average fork length of $23 \mathrm{~cm}$.

In an intensive electrofishing, spring trapping, and angling study of the House River, R.L.\& L (1996) found low to moderate densities of grayling depressed by overharvesting. In 1995, out of 888 fish sampled, 27 fish (3.1\%) were older than 4 years of age and 78 fish $(8.8 \%)$ were older than 3 years of age. These data illustrate a population with moderate recruitment and a high mortality for fish three years of age and older. Three general areas for spawning were recorded in 1994 for this system: Bear Creek, House River mainstem, and Caribou Creek/House River confluence (R.L\&L 1995c). Although this population appeared to be stressed, recruitment of 3-year-old fish still remained. The Alberta Conservation Association (unpubl. data) found a similar size distribution of grayling in the House River between 2000 and 2002, as was present in 1996 (Figure 9). 

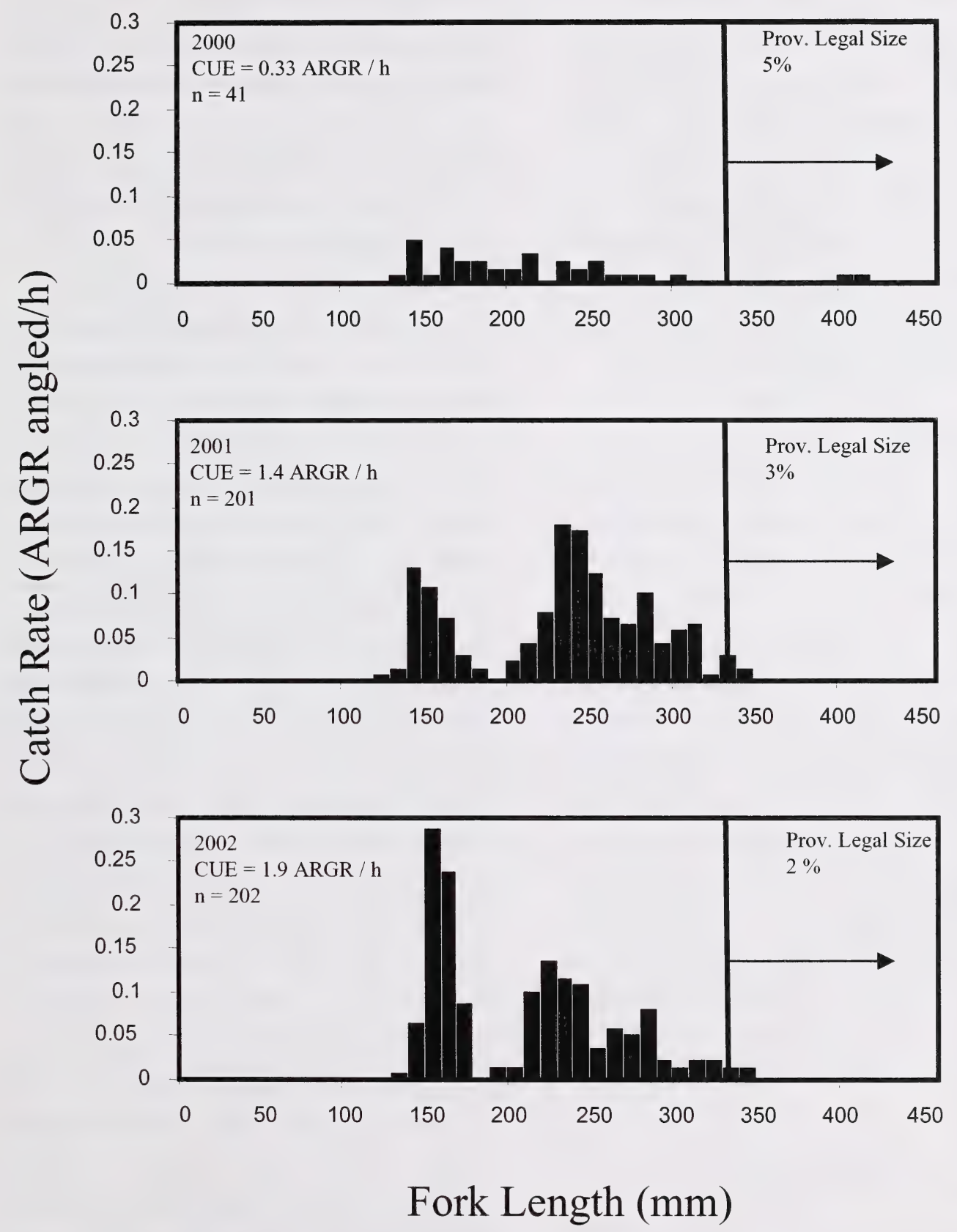

Figure 9. Fork length frequency distributions ( $\mathrm{mm}$ ) of Arctic grayling angled from the House River and tributaries in 2000, 2001 and 2002 (Alberta Conservation Association file data, unpubl. data). $(\mathrm{CUE}=$ catch per unit effort, $\mathrm{ARGR}=$ Arctic grayling $)$. 
In a review of Arctic grayling status in 1988, Sullivan (1988) concluded that grayling in this area had rapid growth rates, high adult mortality rates and early maturity schedules, and that at this time the mortality was likely due to natural factors. He concluded that these fish would be vulnerable to an increase in exploitation pressure. Since this time, extensive road networks have been built, and access along linear developments on all-terrain vehicles has proliferated. Anecdotal information suggests strongly that these populations appear to be at low densities today (C. Davis, pers. comm.)

\section{Other Areas}

By comparison to other populations in North America, populations of grayling in Alberta compose an unknown but small proportion of the populations that occur from Alaska to the Hudson Bay.

Grayling have disappeared from the postglacially isolated Great Lakes-Michigan area as a result of warming of streams, siltation from clear-cut logging in the $1860 \mathrm{~s}$, and replacement by non-native trout species (Behnke 2002). The disjunct Montana populations have been widely supplemented through extensive hatchery propagation and stockings into previously uninhabited waters (Behnke 2002). Stocks in the Williston watershed above the W.A.C. Bennett Dam in British Columbia have declined (Cannings and Ptolemy 1998). Across their range, grayling have been observed to be sensitive to habitat alterations and angling overharvest.

\section{LIMITING FACTORS}

\section{Fragmentation - Movement between} habitats within a drainage is essential for grayling to feed, find areas of optimal thermal habitat, find locations to avoid silt, and to locate suitable spawning and overwintering areas. Stream fragmentation, as a result of road construction and culvert barriers, is a critical limiting habitat feature for Arctic grayling. Even properly installed culverts can become partial or complete barriers to grayling as the crossing ages. Downstream plunge pools become scoured over time, leading to hanging or "perched" culverts, which Arctic grayling cannot navigate. Culverts can also act as velocity barriers in high flows, particularly when culverts are long. Ice-plugged culverts during winter may also impede early spring spawning movements.

No specific study has been conducted to investigate the role of habitat fragmentation on grayling persistence. Stream habitat in Alberta has been fragmented (Shultz and Company Limited 1973, Wilson et al. 2003), however, and continues to be fragmented as a result of road construction. Although mainstem reaches are largely intact through the use of bridges, upstream movements in tributaries are impeded in many grayling streams by poor culvert installations. Managers have found high habitat fragmentation in areas of high road density such as Swan Hills (Freeman River, Sakwatamau River), Drayton Valley (Pembina River, Zeta Creek, Dismal Creek, Paddy Creek, Bigoray River, Rat Creek), Edson (Carrot Creek, Groat Creek, Wolf Creek, Edson River, Sundance Creek, Embarras River, Erith River, Lovett Creek), Grande Prairie (Simonette River), Peace River (Notikewin River), and Fort McMurray (House River, Bear Creek, Christina River, Surmont Creek). In 1973, a study of road crossings in the Edson area noted that 38 of 105 stream crossings $(40 \%)$ observed were considered complete blockages to fish passage (C.D. Shultz and Company Limited 1973). In all cases, it was concluded that the blockages were a result of excessive drop from culvert outlets and that "substantial reduction of migrating populations has already occurred." Road construction in this region has increased tremendously since this time, and habitat fragmentation remains a critical issue for Arctic grayling populations in the Edson and Hinton areas. In a recent study in the Hinton area, of 302 stream crossings investigated, 61 crossings were identified as "potential partial" or "full" barriers to fish passage, although not all streams 
have yet been assessed to be fish-bearing (Wilson et al. 2003). As an example, within the Erith Creek watershed, 11 potential partial or full barriers were identified (Wilson et al. 2003).

Continued fragmentation as a result of largescale road networks in the boreal and foothills regions for resource extraction (Stelfox et al. 2004) will be an important issue affecting grayling persistence in these areas.

The effect of fragmentation by beaver dams on grayling populations has not been quantified, but is often viewed as negative. From a site-specific, short-term perspective, dams can exclude grayling from spawning and rearing tributaries, isolating some populations and leaving them more susceptible to declines; particularly for low gradient populations and in years of low stream flows (O'Neil and Patalas 1995; R.L.\& L. 1995a). Under these conditions, beaver dams may proliferate, restricting water flows, warming the waters, and shifting habitat conditions in favour of predators such as northern pike (Esox lucius). Within a large watershed and a longer time scale, however, there is a frequency of high water events that naturally breach these dams, allowing grayling to use these areas for spawning and rearing, and for previously isolated populations to become reconnected. That grayling and beavers have coexisted for thousands of years would suggest that at a watershed level grayling are adapted to this kind of impermanent fragmentation. Although spawning fidelity has not been well studied, it is likely variable, in order to take advantage of these highly variable environmental conditions.

How beaver dams and road culverts differ in their fragmentation effects is a topic that remains unstudied. However, unlike most road crossings, beaver dams are not permanent. Culvert crossings tend to degrade over time reducing fish passage. Beaver dams degrade over time, and fish passage improves as the dams leak or break. Beaver dams, like local beaver populations, fluctuate over time within a drainage, while culvert crossings tend to proliferate.
2. Overharvest-Grayling in Alberta are at risk of overharvest, even under seemingly very low angler pressure. This high vulnerability to overharvest is a result of a very high catchability for Arctic grayling by angling. Catchability (q) is the proportion of the population harvested with one unit of angling effort (Haddon 2001), and was calculated to be 0.0275 or nearly $3 \%$ of the population for the Kakwa River (data used in Ripley 1998). This is much higher than for other Alberta stream fishes (Figure 10) (Paul et al. 2003). Because of a high catchability, even under catch and release management and low angler pressure, the potential effects of incidental mortalities can be significant management concerns for accessible populations.

Using catchability (q), calculated from the markrecapture population estimate from the Kakwa River (Ripley 1998), exploitation can be modelled under different levels of angler effort (Figure 11). The Kakwa River is a low to moderately angled population. At low levels of incidental mortality $(10 \%)$, the population of Arctic grayling in a $32-\mathrm{km}$ section of the Kakwa River could be overharvested at 35 angler days of effort, and rapidly extirpated at 92 angler days (Figure 11). The overharvest level is equivalent to three parties of four anglers fishing for three days. Incidental mortality is the mortality to the population, in percent, caused by hooking and handling distress and illegal harvest. At $20 \%$ incidental mortality, the effort required to overharvest is much smaller, at only 18 angler days. Although the exact amount of incidental mortality is unknown, as is the potential change in catchability with declining densities, these data highlight the vulnerability to overharvest of grayling at very low angler pressure.

3. Climate - Maximum summer water temperatures may be an important determinant for distribution of Arctic grayling in Alberta ( $\mathrm{J}$. O'Neil, pers. comm.), as a result of the physiological thresholds for grayling. In Alaska, bioassays of juveniles have been shown to have $100 \%$ survival at $22.5^{\circ} \mathrm{C}$, but $0 \%$ survival at $24.5^{\circ} \mathrm{C}$ (LaPerriere and Carlson 1973). Wojcik 


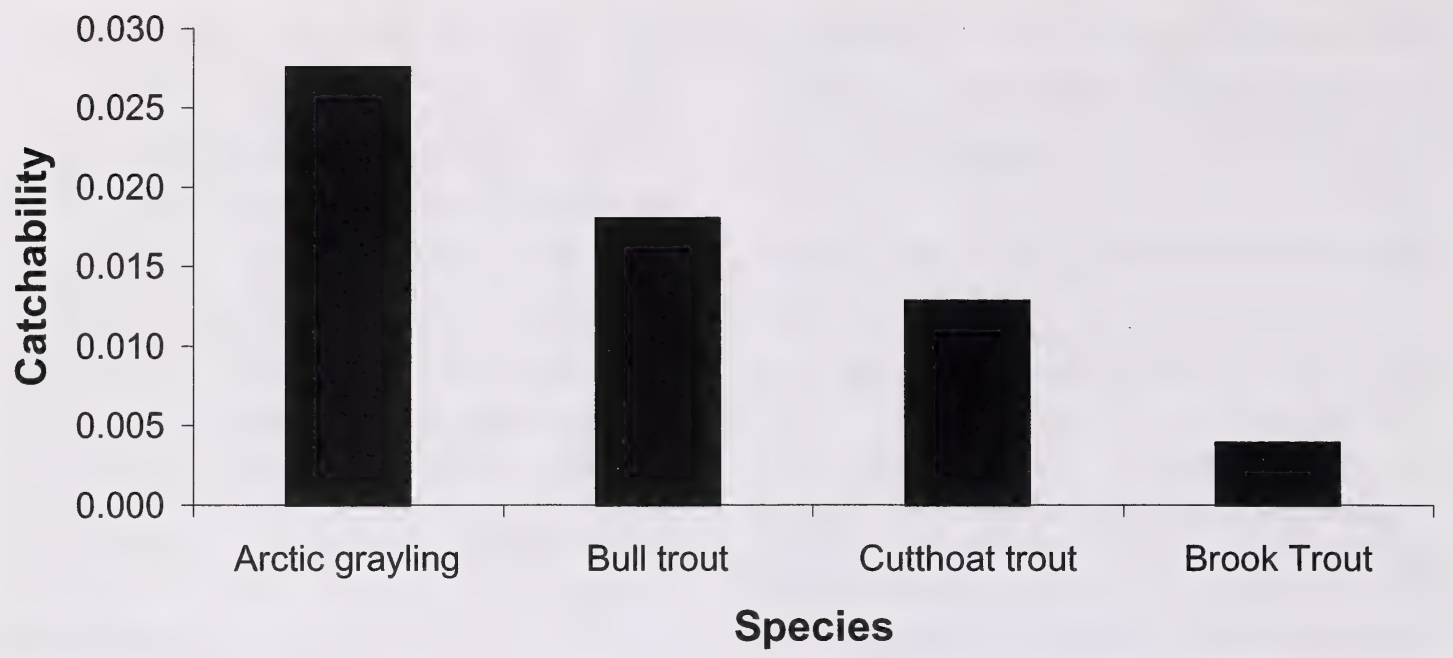

Figure 10. A comparison of Arctic grayling catchability (catchability data: $32 \mathrm{~km}$ of Kakwa River, 12 angler-days, 89 tag-recaptures out of total of 270 grayling tagged [Ripley 1998]) to other Alberta stream fishes (Paul et al. 2003).

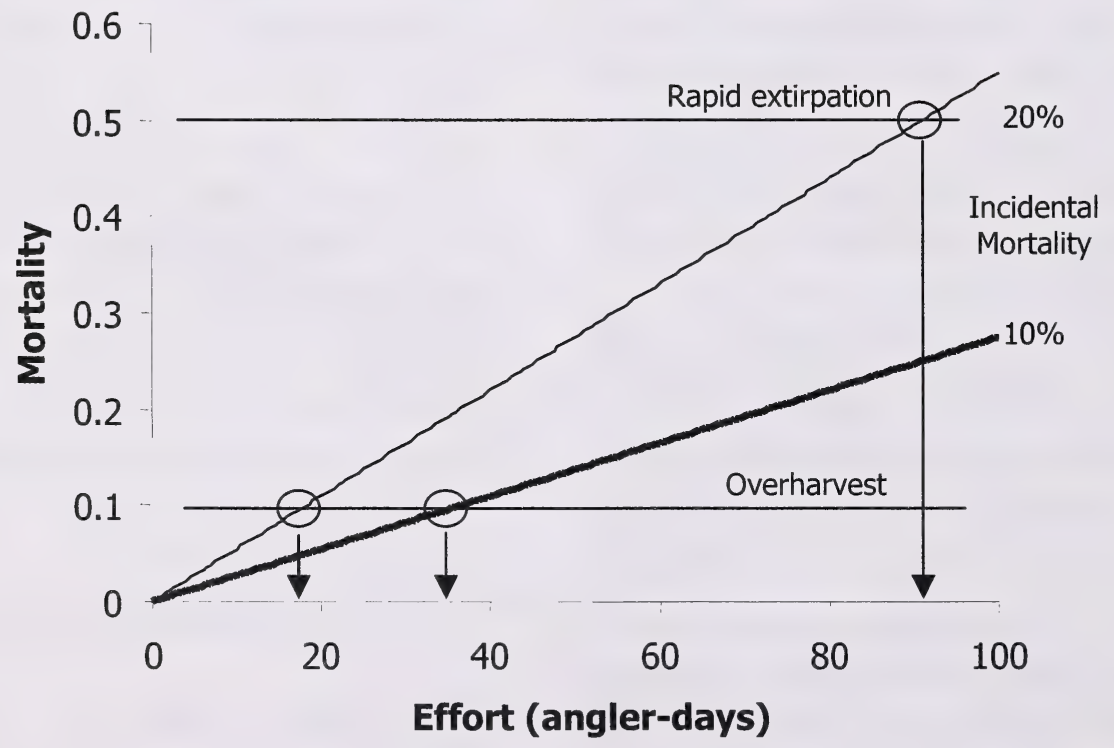

Figure 11. Model of Alberta grayling exploitation at increasing levels of angler effort (M. Sullivan, unpubl. data). Catchability data: $32 \mathrm{~km}$ of Kakwa River, 12 angler-days, 89 tag-recaptures out of total of 270 grayling tagged (Ripley 1998). Overharvest and rapid extirpation $(<5$ years) mortality is based on age-cohort modelling of Alberta grayling (M. Sullivan, pers. comm.). 
(1955) found that adult Arctic grayling were physiologically stressed at $17.2^{\circ} \mathrm{C}$ and avoided $20^{\circ} \mathrm{C}$ water. The historic southern range of Arctic grayling crossing north-central Alberta likely follows these summer maximum water temperatures. High-density populations (historically and currently) have likely been located in areas that have cooler summer temperatures in Alberta. Areas of higher altitude such as northern east slopes foothills, Swan Hills, Caribou Mountains, and Birch Mountain areas have had exceptionally good populations of grayling.

Global climate change models report the potential for warmer air temperatures of $1^{\circ}-2^{\circ} \mathrm{C}$ by mid-century and another $2^{\circ}-4^{\circ} \mathrm{C}$ by 2100 (Hengeveld 2000). As temperature increases there is a higher evaporation potential for rivers and streams. This evaporation may also reduce stream flows in these ephemeral stream systems, reducing habitat even further (Schindler 2001). Research indicates that many boreal streams have already seen decreased flows as a result of the changing climate of the $20^{\text {th }}$ century. The effects of this change on grayling distribution and abundance are unknown. If, however, these populations were already temperature-limited, even higher peak summer temperatures or more frequent high temperature events would affect populations negatively. Populations in lower elevation, warmer areas may be at the highest risk. Connecting grayling distribution with global climate change predictions may provide some insight into the potential effects.

\section{Other Limiting Factors - Cumulative} watershed changes from the development of the oil and gas industry, agriculture, and forestry sectors and their road and installation networks all have incremental effects. Changes in stream flow, temperature, nutrient inputs and siltation all have the potential to affect populations negatively. Whereas competition from nonnative introductions may be a problem in other jurisdictions, particularly in the United States, this is not largely a problem in Alberta.

\section{STATUS DESIGNATIONS}

1 Alberta - Although not listed historically, grayling have been recognized as being a sensitive species. In the Status of the Fish and Wildlife Resource in Alberta (Alberta Energy and Natural Resources 1984), grayling were reported to "be abundant in streams until people gain access to the streams, and then disappear either because of increased silt and/or overfishing." Currently, the Arctic grayling is listed as Sensitive in The General Status of Alberta Wild Species 2000 (Alberta Sustainable Resource Development 2001) and Vulnerable by Alberta's Fisheries Management Division (Berry 1998). The grayling has rankings of G5, N5, and a heritage status rank of S5 for Alberta (NatureServe 2004; see Appendix 1). The origin of the Belly River population is not certain but it may have been stocked from the Upper Missouri River fluvial population. Fish from this drainage in the United States are considered S1 (NatureServe 2004) and NatureServe ranks fish from this drainage in Alberta as SNA and exotic.

2 Other Areas - Arctic grayling have not been considered for a status designation by the Committee on the Status of Endangered Wildlife in Canada, but in February 2004 were determined to be an "intermediate priority candidate" for status evaluation. Grayling are not listed in Wild Species 2000: The General Status of Species in Canada (Canadian Endangered Species Conservation Council 2001). Provincially, grayling in British Columbia are ranked as S4SE (B.C. Conservation Data Centre 2002), but populations in the Williston watershed of British Columbia have a provincial rank of S1 (Cannings and Ptolemy 1998). Populations in Saskatchewan are ranked as S5 (Saskatchewan Conservation Data Centre 2001) and although general grayling populations are unranked in Montana (NatureServe 2004), fluvial populations of the Upper Missouri River

\footnotetext{
* See Appendix 1 for definitions of selected status designations.
} 
in Montana and Wyoming are ranked as S1 (Montana Natural Heritage Information Center 2001, Carlson 2003).

\section{RECENT MANAGEMENT IN ALBERTA}

In response to declines in grayling abundance in many of Alberta's populations, the Fisheries Management Division implemented a provincial management and recovery plan in 1998 (Berry 1998). Minimum size limits for recreational anglers were increased from $30 \mathrm{~cm}$ to $35 \mathrm{~cm}$ and bag limits were reduced from five grayling to two in order to reduce overharvest. Catch-andrelease fisheries were established at some locations, and harvest seasons were reduced to the months of June, July and August.

Fragmentation of habitat and Arctic grayling populations by road crossings in northeastern Alberta is currently being studied at the University of Alberta (D. Park, pers. comm.). Determining the degree of the fragmentation in the northeast boreal region through field study for Arctic grayling and the role of culvert age in the degradation of the installation are key objectives in the study. The potential population effects of the fragmentation are being examined empirically through population modelling and tested through field study. From preliminary models, it appears that even partial blockages by culverts of fish moving upstream to spawn can reduce populations significantly ( $\mathrm{M}$. Sullivan, pers. comm.).

The Alberta Conservation Association intends to conduct a study of grayling abundance trends in the House River drainage in relation to stream flow and temperature (D. Park, pers. comm.).

\section{SYNTHESIS}

Grayling in Alberta are adapted to cool, clear waters and their presence represents the southern edge of their North American range. Populations at the edge of their geographic range often have unique genetic adaptations, as these populations are under selection pressures different from those populations at the center of their range. These unique edge populations are important, in order to conserve the range of genetic diversity for grayling populations in Alberta. Grayling habitat in Alberta has naturally high temperatures and flow variability that likely results in a high and varying natural mortality, particularly for populations along the southern part of the Alberta range and populations with low gradients and low elevations. Biologically, these populations have compensated for this high natural mortality by having early reproductive schedules and fast-growing young. These natural conditions make grayling populations particularly susceptible to extirpation in Alberta.

Of the populations that exist in Alberta, those that exist across the southern limit of their range have experienced the highest population declines. Angling access, habitat fragmentation and water temperature changes have all likely contributed to these declines. Populations that are pristine or have been little affected by these pressures occur only in the most remote portions of the Alberta range. However, with the extent of oil and gas and forestry development in northern Alberta, these previously low-access areas are disappearing.

The risk to grayling as a species stems from the incremental declines and losses of populations across its range and the rate at which these losses are occurring. This rate has been difficult to assess given the minimal information about historical population sizes and the relatively infrequent and inconsistent manner of population assessments across Alberta. Many accessible populations had declined or were all but lost prior to the biological inventories of the late 1900 s. It is unclear whether changes in angler regulations will be enough to recover many populations. The infrequent and inconsistent monitoring of populations also reduces the effectiveness of management to decrease the risks to grayling. 
The quantitative monitoring of population parameters, such as population size, mortality, survival and recruitment, in response to quantified human harvest pressure and land disturbance regimes from a range of consistently monitored populations may be a useful adaptive management approach to explore. This approach may provide valuable information to assess the effectiveness of a range of recovery strategies under different land disturbance, fragmentation and angler harvest regimes. These data will be valuable to examine strategies to minimize the potential effects of recreational and industrial land development. Research into the effects of fragmentation and potential mitigating strategies may also be useful. Genetic studies to understand better the degree of relatedness for stocks in
Alberta may also prove informative in assessing the relative significance of losing a localized stock of grayling and, if necessary, assessing reintroduction strategies. Finally, the development of landscape models that examine the cumulative impact of human disturbances for grayling may be important to link to climate change models to provide a better understanding of the potential risks of development scenarios under proposed climate changes. From these models, we may be able to better manage grayling populations to be as robust as possible, in order to deal with potential climate changes. Arctic grayling may also be a useful indicator species of boreal ecological health because of their sensitivity to environmental change. 


\section{LITERATURE CITED}

Alberta Energy and Natural Resources. 1984. Status of the Fish and Wildlife Resource in Alberta. Alberta Energy and Natural Resources, Fish and Wildlife Division, Edmonton, Alberta. 127 pp.

Alberta Environmental Protection. 1996. The status of Alberta wildlife. Alberta Environmental Protection, Natural Resources Service, Wildlife Management Division. Edmonton, AB. $44 \mathrm{pp}$.

Alberta Forestry, Lands and Wildlife. 1991. The status of Alberta wildlife. Alberta Forestry, Lands and Wildlife, Fish and Wildlife Division. Edmonton, AB. 49 pp.

Alberta Natural Heritage Information Centre (ANHIC). 2002. Rank Definitions. URL: http://www.cd.gov.ab.ca/preserving/ parks/anhic/definitions.asp [Last updated: October 2002].

Alberta Sustainable Resource Development. 2001. The general status of Alberta wild species 2000. Alberta Sustainable Resource Development, Fish and Wildlife Service, Edmonton, AB. 46 pp.

Allan, J.H. 1981. An evaluation of the aquatic resources of three streams in the Edson area. Report prepared by Pisces Environmental Consulting Services Ltd. for NOVA, an Alberta Corporation. 59 pp.+app.

Antoniuk, T.M., and P. Carey. 1979. Interim report on the Foothills Project aquatic baseline assessment, 1978. Prepared for Exploration and Production, Gulf Canada Resources Incorporated, Calgary, AB.

Aquatic Environments Limited (AEL). 1975. Memorandum to Dr. M.J. Paetz, Chief
Fishery Biologist, Edmonton, $\mathrm{AB}$, dated April 01, 1975. 4 pp.

ARDA. 1970. ARDA fisheries capability survey, Edson map sheet (83F) stream evaluation. Report for Alberta Department of Forestry, Lands and Wildlife, Fish and Wildlife Division. Edson, AB, 5 pp.+app.

Ash, G., and J. O’Neil. 1970. Sample record card in Trout Creek file, Edson NRS office, dated June 9-11, 1970. 1 p.

B.C. Conservation Data Centre. 2002. Tracking lists. British Columbia Ministry of Environment, Lands and Parks. URL: http://srmwww.gov.bc.ca/cdc/ [Date accessed: September 5, 2004].

Barber, W.E., H. Hop and J.B.Reynolds. 1985. Autumn movements of Arctic grayling on the Arctic National Wildlife Refuge as determined by radiotelemetry. Proceedings of the 1985 Arctic Science Conference 36:218-219.

Behnke, R.J. 2002. Trout and salmon of North America. The Free Press. New York, New York, USA. 359 pp.

Berndt, D. 1990. Little Smoky River project1989/90. Memorandum to Rudy Hawryluk, Regional Fisheries Technician (on file at Edson Fish and Wildlife), dated May 02, 1990. 16 pp.+app.

Berry, D.K. 1998. Alberta's arctic grayling management and recovery plan. Alberta Environmental Protection, Natural Resources Service, Fisheries Management Division, Edmonton, Alberta. 27 pp.

Brilling, M.K. 1985. A preliminary survey of the Waskahigan River drainage, 1983. 
Report for Alberta Department of Energy and Natural Resources, Fish and Wildlife Division. Lac La Biche 37 pp.+app.

Bryski, M. 1997a. Arctic grayling historical review - grayling fisheries of the Athabasca River sub-basin in Fisheries Management Area 4. Alberta Conservation Association, Edson, Alberta. 81 pp.

Bryski, M. 1997b. Arctic grayling historical review - grayling fisheries of the Berland River Sub-Basin in Fisheries Management Area 4. Alberta Conservation Association, Edson, Alberta. 49 pp.

Bryski, M. 1998. Arctic grayling historical review - grayling fisheries of the Little Smoky River Sub-Basin in Fisheries Management Area 4. Alberta Conservation Association, Edson, Alberta. 42 pp.

Bryski, M. 1999a. Arctic grayling historical review - grayling fisheries of the McLeod River Sub-Basin in Fisheries Management Area 4. Alberta Conservation Association, Edson, Alberta. 83 pp.

Bryski, M. 1999b. Arctic grayling historical review - grayling fisheries of the Pembina River Sub-Basin in Fisheries Management Area 4. Alberta Conservation Association, Edson, Alberta. 52 pp.

Canadian Endangered Species Conservation Council (CESCC). 2001. Wild species 2000: the general status of species in Canada. Ottawa: Minister of Public Works and Government Services Canada. 48 pp.
Cannings, S.B., and J. Ptolemy. 1998. Rare freshwater fish of British Columbia. B.C. Ministry of Environment. 200 pp.

Carlson, J. 2003. Montana Animal Species of Concern, Montana Natural Heritage Program and Montana Fish, Wildlife, and Parks, Helena, Montana. 14 pp.

Cheadle, W.B. 1971. Cheadle's journal of trip across Canada, 1862-1863. M.G. Hurtig Ltd. Booksellers \& Publishers, Edmonton, AB. 311 pp.

COSEWIC. 2004. Database. Committee on the Status of Endangered Wildlife in Canada. URL: http://www.cosewic.gc.ca [Last updated: December 2004].

Craig P.C., and V.A. Poulin. 1975. Movements and growth of Arctic grayling (Thymallus arcticus) and juvenile Arctic char (Salvelinus alpinus) in a small Arctic stream, Alaska. Journal of the Fisheries Research Board of Canada 32:689-697.

Cunningham, B. 1959. Arctic grayling capture record. Data sheet in Little Sundance Creek file, Edson, AB, dated August 04, 1959. 1 p.

Cunningham, E.B. 1960. The Berland drainage stream survey report. Report for Alberta Department of Lands and Resources, Fish and Wildlife Division. 25 pp.

Cunningham, E.B. 1961. Stream survey report - streams in the Chip Lake-Cynthia area. Report for Alberta Department of Lands and Resources, Fish and Wildlife Division. $6 \mathrm{pp}$.

Cunningham, E.B. 1962. Stream survey report Coldwater Creek. Report for Alberta Department of Lands and Resources, Fish and Wildlife Division. 2 pp. 
Doonanco J. 1991. A letter from J. Doonanco (retired Fish and Wildlife Officer) to Carl Hunt (Fisheries Biologist, Edson Area now retired) describing the history of Arctic grayling populations in Northeastern Alberta. File data, Edson, Alberta.

Driscoll, D. 1990. IAC collection of creel data for the month of August 1990. Memorandum to Rudy Hawryluk, Regional Fisheries Technician (on file at Edson Fish \& Wildlife), dated Nov 16, 1990. 6 pp.

Dentherm Resources Ltd. 1982. Coalspur Project, volume 5 Environmental Impact Assessment. Edson, Alberta. 361 pp.+app.

Earle, J. 1996. Memo information from Jenny Earle (R.L.\&L) from the Berland River. Edson Fisheries Management.

Fernet, D., and L. Kratt. (Environmental Management Associates) 1980. Stream surveys along pipeline route-Edson to Grande Prairie, 1980. Report for Alberta Gas Trunk Line (Nova). Calgary, AB.

Gulf Canada Resources Ltd. 1980. Environmental Impact AssessmentFoothills Project-Overview summary and volume 1-biophysical impact assessment. Excerpt pp. 115-190.

Haddon, M. 2001. Modelling and quantitative methods in fisheries. Chapman and Hall/ CRC, Boca Raton, Florida. 406 pp.

Hawryluk, R. 1981. Berland River creel data. Memorandum to Carl Hunt, Regional Fisheries Biologist, Fish and Wildlife, Edson, dated October 16, 1981. 2 pp.

Hengeveld, H.G. 2000. Projections for Canada's climate future: a discussion of recent simulations with the Canadian Global
Climate Model; Environment Canada, Climate Change Digest 00-01, 27 p.

Hildebrand, L. 1981. Aquatic habitat and fisheries studies in the Dismal Creek study area. Report prepared by R.L.\&L. Environmental Services Limited for Petro-Canada Ltd. Calgary, AB. 48 pp.+app.

Hildebrandt, D. 1994. Trout Creek electrofishing-April-May, 1993. Memorandum to Rudy Hawryluk, Fish and Wildlife Technician, Edson, AB, dated February 02, 1994. 2 pp.

Hildebrandt, D., and C. Hunt. 1992. Arctic grayling hooking and tagging mortality and angler catch rates on the Little Smoky River, July and August, 1990. Report for Alberta Department of Forestry, Lands and Wildlife, Fish and Wildlife Division. Edson Alberta 27 pp.+app.

Hills, B. 1983. Phase II survey of Moose Creek (11 of 1-53-17-W5). Report for Alberta Department of Energy and Natural Resources, Fish and Wildlife Division. Edson Alberta 23 pp.+app.

Hills, B. 1984. Phase II survey of Wolf Creek. Report for Alberta Department of Energy and Natural Resources, Fish and Wildlife Division. Edson, AB. 29 pp.+app.

Hominiuk, T. 1985. Phase II survey of Fred Creek (16 of 34-53-1-W6). Report for Alberta Department of Energy and Natural Resources, Fish and Wildlife Division. 23 pp.+app.

Hominiuk, T. 1986a. A phase II survey of Trout Creek (12 of 28-54-15-W5). Report for Alberta Department of Forestry, Lands and Wildlife, Fish and Wildlife Division.Edson, AB. 59 pp.+app. 
Hominiuk, T. 1986b. Phase II survey of Schwartz Creek (a tributary to the McLeod River) (6 of 31-52-17-W5). Report for Alberta Department of Forestry, Lands and Wildlife, Fish and Wildlife Division, Edson AB. 27 pp.+app.

Hop, H., W.E. Barber and J.B. Reynolds. 1986. Telemetry study of autumn migration and winter distribution of Arctic grayling on the Arctic National Wildlife Refuge. Final report to Fishery Resources, Alaska Region, U.S. Fish and Wildlife Service, Unit Co-operative Agreement 14-160009-1532. Alaska Co-operative Fishery Research Unit, University of Alaska, Fairbanks. Unit Contribution No. 21.72 pp.

Hubert, W.A., R.S. Helzner, L.A. Lee and P.C. Nelson. 1985. Habitat suitability index models and instream flow suitability curves: Arctic grayling riverine populations. U.S. Fish and Wildlife Service Biological Report 82 (10.110) 34 pp.

Hughes, N.F. 1999. Population processes responsible for larger-fish-upstream distribution patterns of Arctic grayling in interior Alaskan runoff rivers. Canadian Journal of Fisheries and Aquatic Science 56:2292-2299.

Hughes, N.F., and J.B. Reynolds. 1994. Why do arctic grayling (Thymallus arcticus) get bigger as you go upstream? Canadian Journal of Fisheries and Aquatic Science 51:2154-2163.

IEC Beak Consultants Ltd. 1983. File \#5101.1, Aquatic Investigations, Judy Creek Region. Memorandum to Carl Hunt, Regional Fisheries Biologist, Edson, Alberta. 2 pp.
Johnson, C.F. 1996. Foothills Model Forest Fish Inventory Report - Hightower Creek and Pinto Creek. Foothills Model Forest Fish and Stream Inventory - Fish and Aquatic Habitat Data 1995 - 1996. Foothills Model Forest, Hinton, A.B.

Johnson, C.F., and J. Walker. 1997. Survey of sportfish in upper Sundance Creek, August 1996. Fisheries Management Enhancement Program and Foothills Model Forest Report. Hinton, Alberta. $17 \mathrm{pp}$.

Joint, A., and M.G. Sullivan. 2003. Fish of Alberta. Lone Pine Publishing, Edmonton, Alberta. 176 pp.

Kauffman, C. 1992. Berland River mountain whitefish creel survey. Memorandum to Rudy Hawryluk, Fisheries Technician FMA 4, dated December 15, 1992. 2 pp.

Krueger, S.W. 1981. Freshwater habitat relationships: Arctic grayling (Thymallus arcticus). Alaska Department of Fish and Game. 65 pp.

LaPerriere, J.D., and R.F. Carlson. 1973. Thermal tolerances of interior Alaskan Arctic grayling, Thymallus arcticus. Institute of Water Resources Report IWR-46. University of Alaska, Fairbanks. 36 pp.

Manalta Coal Ltd. 1982. McLeod River Project: Volume II - Environmental Impact Assessment. Application no. 820294 submitted to Energy Resources Conservation Board. - Volumes 2 and 3 comprise the environmental impact assessment, submitted to Alberta Environment, Environmental Assessment Division. 
McPhail, J.D., and C.C. Lindsey. 1970. Freshwater fishes of northwestern Canada and Alaska. Fisheries Research Board of Canada. Bulletin 173, 125-128.

Miller, R.B., and W.H. Macdonald. 1949. Preliminary biological surveys of Alberta watersheds. Report for Alberta Department of Lands and Forest, Fish and Wildlife Division. 139 pp.

Montana Natural Heritage Information Center. 2001. Species of special concern: watch lists. Natural Heritage Network. URL: http://nris.state.mt.us/mtnhp [Date accessed: January 8, 2004].

National Research Council. 1995. Science and the Endangered Species Act. National Academy Press, Washington, DC. 271 pp.

NatureServe. 2004. NatureServe Explorer: An online encyclopedia of life [web application]. Version 4.0. NatureServe, Arlington, Virginia. URL: http:// natureserve.org/explorer. [Last updated: November 2004].

Nelson, J.S., and M.J. Paetz. 1992. The fishes of Alberta. $2^{\text {nd }}$ Edition. University of Alberta Press, University of Alberta, Edmonton, Alberta, Canada. 438 pp.

O’Neil, J., and J. Patalas 1995. Fisheries investigations of Rat Creek 1991-1992. Report prepared by R.L.\&L. Environmental Services Limited for Trout Unlimited Canada and Alberta Department of Environmental Protection, Fish and Wildlife Division. City, AB. 63 pp.+app.

O’Neil, J., C. Pattenden and R. Pattenden 1988. Inventory of aquatic resources in the Lovett River, Alberta. Report prepared by R.L.\&L. Environmental Services Limited for Luscar Sterco (1977) Ltd. Edmonton, AB. 51pp.+app.
Paetz, M.J. 1953. Observations on the McLeod River, 1953. Report for Alberta Department of Lands and Resources, Fish and Wildlife Division. Edmonton, AB. 8 pp.

Park, D. in prep. Master's of Science thesis on the effects of hanging culverts on habitat fragmentation and grayling. Department of Biology, University of Alberta, Edmonton, Alberta.

Paul, A., J. Post and J. Stelfox. 2003. Can anglers influence the abundance of native and non-native salmonids in a stream from the Canadian Rocky Mountains? North American Journal of Fisheries Management. 23:109-119.

Ripley, T. 1998. A stock assessment of the Kakwa River Arctic grayling (Thymallus arcticus) population, fall 1997. Alberta Conservation Association, Fisheries Management Division, Northwest Boreal Region. 23 pp.

Ripley, T. 2003. Arctic grayling regulation review and data summary. Northwest Region, Alberta Sustainable Resource Development. $16 \mathrm{pp}$.

R.L.\&L. Environmental Services Ltd. 1979. Gulf Resources-Foothills Project Fisheries Data. Appendix. Copy in Edson Fish and Wildlife Office.

R.L.\&L. Environmental Services Ltd. 1993. Wildhay River fisheries enhancement study. Report for Alberta Environmental Protection, Fish and Wildlife Division. 85 pp.+app.

R.L.\&L. Environmental Services Ltd. 1994. Northern River Basins Study Project Report No. 32, A general fish and riverine habitat inventory - Athabasca River, 1992. Edmonton, Alberta, Canada. 74p.+app. 
R.L.\&L. Environmental Services Ltd. 1995a. Fisheries investigation of Sundance and Little Sundance creeks, 1991-1992. Report prepared for Trout Unlimited Canada and Alberta Fish and Wildlife. R.L.\&L. Report No. 303F: 72 pp.+app.

R.L.\&L. Environmental Services Ltd. 1995b. Upstream fish movements and population densities in Sundance Creek, Alberta, 1993. Draft report prepared for Trout Unlimited Canada and Alberta Fish and Wildlife. R.L.\&L. Report No. 369D: 35 pp.+app.

R.L.\& L Environmental Services Ltd. 1995c. Arctic grayling spawning study in the House River drainage of northeastern Alberta, 1994. . Prepared for Alberta Environmental Protection, Fish and Wildlife Services, Lac La Biche Alberta. 50 pp.+app.

R.L.\&L. Environmental Services Ltd. 1996. Population status and seasonal distribution of Arctic grayling in the House River drainage of northeastern Alberta, 1995. Prepared for Alberta Environmental Protection, Fish and Wildlife Services, Lac La Biche Alberta. 34 pp.+app.

Saskatchewan Conservation Data Centre. 2001. Vertebrate Species Lists. URL: http:// www.biodiversity.sk.ca/FTP.htm [Date accessed: January 8, 2004].

Schindler, D. 2001. The cumulative effects of climate warming and other human stresses on Canadian freshwaters in the new millennium. Canadian Journal of Fisheries and Aquatic Sciences 58:18-29.

Schultz, C.D. and Company Limited. 1973. The environmental effects of timber harvesting operations in the Edson and Grande Prairie forests of Alberta.
Volumes 1 and 2. Prepared for The Minister of Lands and Forests, Government of Alberta, Edmonton, Canada. 280 pp.+app.

Scott, W.B., and E.J. Crossman. 1985. Freshwater fishes of Canada. Fisheries Research Board of Canada Bulletin 184. $966 \mathrm{pp}$.

Seidel, K. 1983. Phase II survey of Hansen Creek, September 1983. Report for Alberta Department of Energy and Natural Resources, Fish and Wildlife Division.Edson, AB. 40 pp.+app.

Snyder, S.V. 1971. Report on Sundance Lake survey, 1971. Report to C.B. Lane, Regional Fisheries Biologist, Alberta Fish and Wildlife. 24p.+app.

Stanislawski, S. 1997. Fall and winter movements of Arctic grayling (Thymallus arcticus) in the Little Smoky River, Alberta. M.Sc. Thesis. Department of Biological Sciences, University of Alberta, Edmonton, Alberta. 91 pp.

Stanislawski, S.1998. Stream inventory of Alberta's northeast boreal forest, 1997. Prepared for Alberta Pacific Forest Industries Inc. and Alberta Conservation Association by FRM Environmental Consulting Ltd. 367 pp.

Stanislawski, S. 1999. Sport fish inventory of the House River drainage, Alberta, 1998. Prepared for the Alberta Conservation Association by FRM Environmental Consulting Ltd. 124 pp.

Stanislawski, S., and R.S. Brown. 1996. Stream inventory of Alberta's northeast boreal forest. Prepared for Alberta Pacific Forest Industries Inc. by FRM Environmental Consulting Ltd. 325 pp. 
Stelfox, J.B., M. Sullivan and M. Spafford. 2004. The role of integrated landscape management to assist with exploring the past, present, and future effects of landscape activities on Alberta's boreal fish communities. Pp 9-10 in G.J. Scrimgeour, G. Eisler, B. McCulloch, U. Silins and M. Monita. Proceedings of: Forest Land - Fish Conference II: Ecosystem Stewardship Through Collaboration. Edmonton, Alberta, Canada, April 26-28th, 2004.

Sterling, G. 1987a. A phase II survey of Tony Creek LSD 4 of 23-62-21-W5. Report for Alberta Department of Forestry, Lands and Wildlife, Fish and Wildlife Division.Edson, AB. 34 pp.+app.

Sterling, G. 1987b. A phase II survey of unnamed creek (Twin City Creek) LSD 3 of 1-6121-W5. Report for Alberta Department of Forestry, Lands and Wildlife, Fish and Wildlife Division. 20 pp.+app.

Sterling, G. 1987c. A phase II survey of unnamed creek (Bird Creek) LSD 13 of 5-61-21W5. Report for Alberta Department of Forestry, Lands and Wildlife, Fish and Wildlife Division. Edson, AB. 24 pp.+app.

Sterling, G. 1987d. A phase II survey of unnamed creek (South Lake Creek) LSD 2 of 361-22-W5. Report for Alberta Department of Forestry, Lands and Wildlife, Fish and Wildlife Division. Edson, AB. 22 pp.+app.

Sterling, G. 1987e. A phase II survey of unnamed creek (LSD 14 of 17-60-23-W5. Report for Alberta Department of Forestry, Lands and Wildlife, Fish and Wildlife Division, Edson, AB. 20 pp.+app.

Sterling, G., and C. Hunt. 1989. Preliminary survey: Arctic grayling movements and age and growth in the Little Smoky
River, Alberta, 1987 and 1988. Report for Alberta Department of Forestry, Lands and Wildlife, Fish and Wildlife Division. 29 pp.+app.

Sullivan, M.G. 1988. Status of Arctic grayling populations in the Northeast Region. Report for Alberta Department of Forestry, Lands and Wildlife, Fish and Wildlife Division. 14 pp.

Sullivan, M.G. 1996. Sampling of Arctic grayling from Little Smoky River, August 1996, preliminary summary. Memorandum to Carl Hunt, Regional Fisheries Biologist (on file at Edson Fish and Wildlife), dated August 29, 1996. 10 pp.

Sullivan, M.G. 2005. Alberta Arctic grayling status-changes in historical range. Memorandum to Sue Cotterill, Acting Provincial Species at Risk Specialist (on file at Great West Life Building, Sustainable Resource Development, Edmonton, Alberta).

Sullivan, M.G., and C. Johnson. 1994. Arctic grayling sampled from Little Smoky River, August 1994. Memorandum to Carl Hunt, Regional Fisheries Biologist (on file at Edson Fish and Wildlife), dated September 20, 1994. 8 pp.

Tack, S.L. 1980. Migrations and distributions of Arctic grayling in interior and Arctic Alaska. Alaska Department of Fish and Game, Federal Aid in Fish Restoration Annual Performance Report, 1979-1980. Project F-9-12, 21 (R-1).

Tchir, J., A. Wildeman and P. Hvenegaard. 2003. Wapiti watershed study final report 2002. Alberta Conservation Association, Northwest Boreal Region. 76 pp.

Tchir, J.P., P.J. Hvenegaard and G. Scrimgeour. in prep. Stream crossing inventories in the Swan and Notikewin River Basins 
of Northwest Alberta: resolution at the watershed scale. $18 \mathrm{pp}$.

Techman Engineering Limited. 1981. Pembina Pipe Line Limited Permit Application "Segregated Condensate System". Report for Pembina Pipe Line Limited. Excerpt p.45-55, 82-88.

Thomas, R.C. 1956. Report on Bigoray Creek. Report for Alberta Department of Lands and Resources, Fish and Wildlife Division.Edson, Alberta 3 pp.

Thornton, M. 1983. Phase II survey of Wroe Creek. Report for Alberta Department of Energy and Natural Resources, Fish and Wildlife Division. 25 pp.

Tripp, D.B., and P.T.P. Tsui. 1980. Fisheries and habitat investigations of tributary streams in the southern portion of the AOSERP study area. Alberta Oil Sands Environmental Research Program, Report 92.

Valastin, P., and M. G. Sullivan. 1997. A historical survey of sport fisheries in northeastern Alberta from 1920 to 1975.
Alberta Environmental Protection, Natural Resources Service, Fisheries Management Enhancement Program Reports, Edmonton, AB.

Ward, J.C. 1951. The biology of Arctic grayling in the southern Athabasca drainage. M.Sc. Thesis, University of Alberta. 64 pp.+app.

West, R.L., M.W. Smith, W.E. Barber, J.B. Reynolds and H. Hop. 1992. Autumn migration and overwintering of Arctic grayling in coastal streams of the Arctic National Wildlife Refuge, Alaska. Transactions of the American Fisheries Society 121:709-715.

Wilson, S., R. McCleary and C. Bambrick. 2003. Overview assessment of fish passage at stream crossings within selected watersheds. Report 2.3. Foothills Model Forest. Hinton, Alberta. 36 pp.

Wojcik, F. 1955. Life history and management of the grayling in interior Alaska. M.Sc. Thesis, University of Alaska, Fairbanks. $54 \mathrm{pp}$. 
Appendix 1. Definitions of selected legal and protective designations.

A. The General Status of Alberta Wild Species 2000 (after Alberta Sustainable Resource Development 2001)

\begin{tabular}{|c|c|c|}
\hline 2000 Rank & 1996 Rank & Definitions \\
\hline At Risk & Red & $\begin{array}{l}\text { Any species known to be At Risk after formal detailed status } \\
\text { assessment and designation as Endangered or Threatened in } \\
\text { Alberta. }\end{array}$ \\
\hline May Be At Risk & Blue & $\begin{array}{l}\text { Any species that may be at risk of extinction or extirpation, and is } \\
\text { therefore a candidate for detailed risk assessment. }\end{array}$ \\
\hline Sensitive & Yellow & $\begin{array}{l}\text { Any species that is not at risk of extinction or extirpation but may } \\
\text { require special attention or protection to prevent it from becoming } \\
\text { at risk. }\end{array}$ \\
\hline Secure & Green & Any species that is not At Risk, May Be At Risk or Sensitive. \\
\hline Undetermined & $\begin{array}{l}\text { Status } \\
\text { Undetermined }\end{array}$ & $\begin{array}{l}\text { Any species for which insufficient information, knowledge or data } \\
\text { is available to reliably evaluate its general status. }\end{array}$ \\
\hline Not Assessed & $\mathrm{n} / \mathrm{a}$ & $\begin{array}{l}\text { Any species known or believed to be present but which has not yet } \\
\text { been evaluated. }\end{array}$ \\
\hline Exotic/Alien & $\mathrm{n} / \mathrm{a}$ & $\begin{array}{l}\text { Any species that has been introduced as a result of human } \\
\text { activities. }\end{array}$ \\
\hline Extirpated/Extinct & $\mathrm{n} / \mathrm{a}$ & $\begin{array}{l}\text { Any species no longer thought to be present in Alberta } \\
\text { (Extirpated) or no longer believed to be present anywhere in the } \\
\text { world (Extinct). }\end{array}$ \\
\hline Accidental/Vagrant & $\mathrm{n} / \mathrm{a}$ & $\begin{array}{l}\text { Any species occurring infrequently and unpredictably in Alberta, } \\
\text { i.e., outside its usual range. }\end{array}$ \\
\hline
\end{tabular}

\section{B. Alberta Wildlife Act/Regulation}

Species designated as Endangered under Alberta's Wildlife Act include those listed as Endangered or Threatened in the Wildlife Regulation.

\begin{tabular}{|l|l|}
\hline Endangered & A species facing imminent extirpation or extinction. \\
\hline Threatened & A species that is likely to become endangered if limiting factors are not reversed. \\
\hline
\end{tabular}

C. Committee on the Status of Endangered Wildlife in Canada (after COSEWIC 2004)

\begin{tabular}{|l|l|}
\hline Extinct & A species that no longer exists. \\
\hline Extirpated & A species that no longer exists in the wild in Canada, but occurs elsewhere. \\
\hline Endangered & A species facing imminent extirpation or extinction. \\
\hline Threatened & A species that is likely to become endangered if limiting factors are not reversed. \\
\hline Special Concern & $\begin{array}{l}\text { A species of special concern because of characteristics that make it particularly } \\
\text { sensitive to human activities or natural events. }\end{array}$ \\
\hline Not at Risk & A species that has been evaluated and found to be not at risk. \\
\hline Data Deficient & $\begin{array}{l}\text { A species for which there is insufficient scientific information to support status } \\
\text { designation. }\end{array}$ \\
\hline
\end{tabular}


Appendix 1 continued.

D. Heritage Status Ranks: Global (G), National (N), Sub-National (S) (after Alberta Natural Heritage Information Centre 2002, NatureServe 2004)

\begin{tabular}{|l|l|}
\hline G1/N1/S1 & $\begin{array}{l}5 \text { or fewer occurrences or only a few remaining individuals. May be especially } \\
\text { vulnerable to extirpation because of some factor of its biology. }\end{array}$ \\
\hline G2/N2/S2 & $\begin{array}{l}6 \text { to } 20 \text { or fewer occurrences or with many individuals in fewer locations. May be } \\
\text { especially vulnerable to extirpation because of some factor of its biology. }\end{array}$ \\
\hline G3/N3/S3 & $\begin{array}{l}21 \text { to } 100 \text { occurrences, may be rare and local throughout its range, or in a restricted } \\
\text { range (may be abundant in some locations). May be susceptible to extirpation } \\
\text { because of large-scale disturbances. }\end{array}$ \\
\hline G4/N4/S4 & Typically > 100 occurrences. Apparently secure. \\
\hline G5/N5/S5 & Typically > 100 occurrences. Demonstrably secure. \\
\hline GX/NX/SX & Believed to be extinct or extirpated, historical records only. \\
\hline GH/NH/SH & Historically known, may be relocated in the future. \\
\hline GNR/NNR/SNR & Unranked - conservation status not yet assessed. \\
\hline
\end{tabular}

E. United States Endangered Species Act (after National Research Council 1995)

\begin{tabular}{|l|l|}
\hline Endangered & $\begin{array}{l}\text { Any species which is in danger of extinction throughout all or a significant portion of } \\
\text { its range. }\end{array}$ \\
\hline Threatened & $\begin{array}{l}\text { Any species which is likely to become an endangered species within the foreseeable } \\
\text { future throughout all or a significant portion of its range. }\end{array}$ \\
\hline
\end{tabular}


Appendix 2. Rivers with grayling subpopulations in Alberta showing probable declines. An estimated $50 \%$ of grayling subpopulations declined in abundance in the 1950s to 1970 s (Sullivan 2005).

\author{
Baptiste \\ Beaverlodge \\ Berland \\ Calling \\ Christina \\ Clearwater \\ Driftpile \\ Driftwood \\ East and West Prairie \\ Freeman \\ Goose (Christina Basin) \\ Goose (Sturgeon Lake) \\ Hangingstone \\ House \\ Inverness \\ Jackfish \\ La Biche \\ Lesser Slave \\ Martin \\ McLeod \\ Muskeg \\ Notikewin \\ Otauwau \\ Pembina \\ Saulteaux \\ Sundance \\ Swan \\ Tawatina \\ Waskihegan \\ Wildhay
}


Appendix 3. Summary of Arctic grayling abundance data in the McLeod River sub-basin. The sources of this information are Alberta Sustainable Resource Development reports, memos and files, as well as environmental consultants studies produced for industry, stakeholder groups or government (taken from Bryski 1999a).

\begin{tabular}{|c|c|c|c|}
\hline Stream & ARGR abundance (method \& effort) & Source & Comments \\
\hline $\begin{array}{l}\text { McLeod } \\
\text { River }\end{array}$ & $0.02 / \mathrm{m}(70 \mathrm{~mm}$ gill net, effort unknown) & Paetz 1953 & at the Big Eddy \\
\hline Trout Creek & $\begin{array}{l}3 \text { ARGR (angling, effort unknown) } \\
0.20 / \mathrm{m} \text { ( } 53 \text { mm gill net, effort unknown) } \\
2 \text { ARGR (angling, effort unknown) } \\
\text { 1.64/min (electrofishing, } 940 \mathrm{~s} \text { ) }\end{array}$ & $\begin{array}{l}\text { Ash and O'Neil } \\
1970 \\
\text { Hominiuk 1986a } \\
\text { Hominiuk 1986a } \\
\text { Hildebrandt } 1994\end{array}$ & $\begin{array}{l}\text { phase II } \\
\text { phase II }\end{array}$ \\
\hline Edson River & 2 ARGR (angling, effort unknown) & ARDA 1970 & \\
\hline Wolf River & $0.333 / 100 \mathrm{~m}$ (electrofishing, $300 \mathrm{~m})$ & Hills 1984 & phase II \\
\hline Moose Creek & $0.03 / \mathrm{m}(51,64 \mathrm{~mm}$ gill net $)$ & Hills 1983 & phase II \\
\hline $\begin{array}{l}\text { Schwartz } \\
\text { Creek }\end{array}$ & $\begin{array}{l}25 \text { ARGR (electrofishing, effort } \\
\text { unknown) } \\
3.50 / 100 \text { m (electrofishing, } 200 \mathrm{~m} \text { ) } \\
1 \text { ARGR (angling, effort unknown) }\end{array}$ & $\begin{array}{l}\text { Allan } 1981 \\
\text { Hominiuk 1986b } \\
\text { Hominiuk 1986b }\end{array}$ & $\begin{array}{l}24 \text { young of the year and } 1 \text { adult } \\
\text { phase II } \\
\text { phase II }\end{array}$ \\
\hline $\begin{array}{l}\text { Sundance } \\
\text { Creek }\end{array}$ & $\begin{array}{l}4 \text { ARGR (angling, effort unknown) } \\
5 \text { ARGR (angling, effort unknown) } \\
0.29 / \text { min (electrofishing, } 45223 \mathrm{~s} \text { ) } \\
0.16 / \text { min (electrofishing, } 13933 \mathrm{~s} \text { ) } \\
0.29 / \text { day (trap, } 20.7 \text { days) } \\
0.05 / \text { day (trap, } 20.2 \text { days) } \\
0.02 / \text { hour (angling, } 200 \mathrm{hrs)}\end{array}$ & $\begin{array}{l}\text { ARDA } 1970 \\
\text { Snyder } 1971 \\
\text { R.L.\&L. 1995a } \\
\text { R.L.\&L. 1995b } \\
\text { R.L.\&L. 1995b } \\
\text { R.L.\&L. 1995b } \\
\text { Johnson and } \\
\text { Walker (1997) }\end{array}$ & $\begin{array}{l}\text { spring, } 3 \text { caught near lake, one } \\
\text { near McLeod } \\
\text { near lake, one evening } \\
\text { total of all sites for spring, } \\
\text { summer, fall 1991-2 } \\
\text { total of all sites, spring } 1993 \\
\text { spring run, downstream of Hwy } \\
43 \\
\text { spring run, upstream of Hwy } 43 \\
\text { upstream of Highway } 43 \text { to lake }\end{array}$ \\
\hline $\begin{array}{l}\text { Little } \\
\text { Sundance } \\
\text { Creek }\end{array}$ & $\begin{array}{l}14 \text { ARGR (angling, effort unknown) } \\
0.05 / \text { min (electrofishing, } 10676 \mathrm{~s} \text { ) }\end{array}$ & $\begin{array}{l}\text { Cunningham } 1959 \\
\text { R.L.\&L. 1995a }\end{array}$ & $\begin{array}{l}\text { total of all sites for spring, } \\
\text { summer, fall 1991-2 }\end{array}$ \\
\hline $\begin{array}{l}\text { Embarras } \\
\text { River }\end{array}$ & $\begin{array}{l}1 \text { ARGR (electrofishing, effort } \\
\text { unknown) } \\
1 \text { ARGR (electrofishing, effort } \\
\text { unknown) } \\
8 \text { ARGR (angling, effort unknown) } \\
1 \text { ARGR (electrofishing, effort } \\
\text { unknown) }\end{array}$ & $\begin{array}{l}\text { R.L.\&L. } 1979 \\
\text { Antoniuk and } \\
\text { Carey } 1979 \\
\text { Antoniuk and } \\
\text { Carey } 1979 \\
\text { Dentherm } \\
\text { Resources } 1982\end{array}$ & $\begin{array}{l}\text { includes seining and netting, } \\
\text { ARGR }=2.6 \% \text { of total catch }\end{array}$ \\
\hline
\end{tabular}




\begin{tabular}{|c|c|c|c|}
\hline $\begin{array}{l}\text { Rodney } \\
\text { Creek }\end{array}$ & $\begin{array}{l}4.675 / 100 \mathrm{~m} \text { (electrofishing, } 770 \mathrm{~m}) \\
2.338 / 100 \mathrm{~m} \text { (electrofishing, } 770 \mathrm{~m})\end{array}$ & $\begin{array}{l}\text { Allan } 1981 \\
\text { Allan } 1981\end{array}$ & also did population estimate \\
\hline Erith River & $\begin{array}{l}2 \text { ARGR (electrofishing, effort } \\
\text { unknown) } \\
\text { 2.75/day (trap, } 4 \text { days) } \\
2 \text { ARGR (electrofishing, effort } \\
\text { unknown) }\end{array}$ & $\begin{array}{l}\text { R.L.\&L. } 1979 \\
\text { R.L.\&L. } 1979 \\
\text { Dentherm } \\
\text { Resources } 1982\end{array}$ & $\begin{array}{l}\text { includes seining and netting, } \\
\text { ARGR }=0.2 \% \text { of total catch }\end{array}$ \\
\hline Hanlan Creek & $\begin{array}{l}1 \text { ARGR (electrofishing, effort } \\
\text { unknown) } \\
1 \text { ARGR (angling, effort unknown) }\end{array}$ & $\begin{array}{l}\text { Antoniuk and } \\
\text { Carey } 1979 \\
\text { Antoniuk and } \\
\text { Carey } 1979\end{array}$ & \\
\hline $\begin{array}{l}\text { Lendrum } \\
\text { Creek }\end{array}$ & $\begin{array}{l}4 \text { ARGR (electrofishing, effort } \\
\text { unknown) }\end{array}$ & R.L.\&L. 1979 & \\
\hline Lund Creek & $\begin{array}{l}\text { 1 ARGR (electrofishing, effort } \\
\text { unknown) }\end{array}$ & $\begin{array}{l}\text { Antoniuk and } \\
\text { Carey } 1979\end{array}$ & \\
\hline $\begin{array}{l}\text { Mitchell } \\
\text { Creek }\end{array}$ & $\begin{array}{l}1 \text { ARGR (electrofishing, effort } \\
\text { unknown) }\end{array}$ & $\begin{array}{l}\text { Antoniuk and } \\
\text { Carey } 1979\end{array}$ & \\
\hline \multicolumn{4}{|c|}{ McLeod River Mainstem Tributaries } \\
\hline White Creek & $\begin{array}{l}3 \text { ARGR (electrofishing, effort } \\
\text { unknown) } \\
16 \text { ARGR (electrofishing, angling, effort } \\
\text { unknown) }\end{array}$ & $\begin{array}{l}\text { R.L.\&L. } 1979 \\
\text { Manalta Coal } 1982\end{array}$ & \\
\hline $\begin{array}{l}\text { McPherson } \\
\text { Creek }\end{array}$ & $\begin{array}{l}7 \text { ARGR (electrofishing, angling, effort } \\
\text { unknown) }\end{array}$ & Manalta Coal 1982 & \\
\hline
\end{tabular}


Appendix 4. Summary of Arctic grayling abundance data in the Pembina River sub-basin. The sources of this information are Alberta Sustainable Resource Development reports, memos and files, as well as environmental consultants studies produced for industry, stakeholder groups or government (taken from Bryski 1999b).

\begin{tabular}{|c|c|c|c|}
\hline Stream & ARGR abundance (method \& effort) & Source & Comments \\
\hline $\begin{array}{l}\text { Pembina } \\
\text { River }\end{array}$ & 2 ARGR (seining, effort unknown) & R.L.\&L. 1979 & \\
\hline Cold Creek & $\begin{array}{l}\text { 100/day (trap, } 5 \text { days) } \\
6 \text { ARGR (rotenone application) }\end{array}$ & $\begin{array}{l}\text { Ward } 1951 \\
\text { Cunningham } 1962\end{array}$ & $\begin{array}{l}\text { spawning run, approx. } 100 / \text { day for } \\
5 \text { days at peak, lesser numbers } \\
\text { before and after peak } 5 \text { days } \\
\text { downstream of Hwy } 16\end{array}$ \\
\hline Brule Creek & $>100 /$ day (trap, 2 days) & Ward 1951 & spawning run, below beaver dam \\
\hline $\begin{array}{l}\text { Bigoray } \\
\text { River }\end{array}$ & 6 ARGR (angling, effort unknown) & Thomas 1956 & angling considered very good \\
\hline Rat Creek & $\begin{array}{l}1.33 / 100 \mathrm{~m} \text { (electrofishing, } 2106 \mathrm{~m}) \\
0.57 / 100 \mathrm{~m} \text { (electrofishing, } 2106 \mathrm{~m}) \\
0.285 / 100 \mathrm{~m} \text { (electrofishing, } 2106 \mathrm{~m})\end{array}$ & $\begin{array}{l}\text { O'Neil and Patalas } \\
1995 \\
\text { O'Neil and Patalas } \\
1995 \\
\text { O'Neil and Patalas } \\
1995\end{array}$ & $\begin{array}{l}\text { all sites, summer } 1991 \\
\text { all sites, fall } 1991 \\
\text { all sites, spring } 1992\end{array}$ \\
\hline $\begin{array}{l}\text { Dismal } \\
\text { Creek }\end{array}$ & $\begin{array}{l}0.07 / \text { min (electrofishing, } 850 \mathrm{~s} \text { ) } \\
2 \text { ARGR (electrofishing, effort } \\
\text { unknown) } \\
1 \text { ARGR (trap, effort unknown) } \\
58 \text { ARGR (trap, effort unknown) } \\
3 \text { ARGR (SCUBA, effort unknown) }\end{array}$ & $\begin{array}{l}\text { Techman } \\
\text { Engineering } 1981 \\
\text { Hildebrand } 1981 \\
\text { Hildebrand } 1981 \\
\text { Hildebrand } 1981 \\
\text { Hildebrand } 1981\end{array}$ & $\begin{array}{l}\mathrm{km} 25.8 \\
\mathrm{~km} 13.6 \\
\mathrm{~km} 39.8 \\
\mathrm{~km} 29.3\end{array}$ \\
\hline Zeta Creek & $\begin{array}{l}13 \text { ARGR (fyke and gill nets, effort } \\
\text { unknown) }\end{array}$ & IEC Beak 1983 & \\
\hline $\begin{array}{l}\text { Unnamed } \\
\text { Creek } \\
\text { (Creek A) } \\
(47-17-W 5)\end{array}$ & $\begin{array}{l}2 \text { ARGR (electrofishing, effort } \\
\text { unknown) } \\
9 \text { ARGR (electrofishing and angling, } \\
\text { effort unknown) } \\
4 \text { ARGR (method unknown, effort } \\
\text { unknown) } \\
1 \text { ARGR (angling, effort unknown) }\end{array}$ & $\begin{array}{l}\text { Antoniuk and Carey } \\
1979 \\
\text { Antoniuk and Carey } \\
1979 \\
\text { Antoniuk and Carey } \\
1979 \\
\text { Antoniuk and Carey } \\
1979\end{array}$ & \\
\hline
\end{tabular}




\begin{tabular}{|c|c|c|c|}
\hline Lovett River & $\begin{array}{l}\text { 1 ARGR (electrofishing, effort } \\
\text { unknown) } \\
\text { 15 ARGR (electrofishing and angling, } \\
\text { effort unknown) } \\
0.51 / 100 \text { m (electrofishing, } 2106 \mathrm{~m} \text { ) } \\
2.40 / 100 \text { m (electrofishing, } 2106 \mathrm{~m} \text { ) } \\
1.14 / 100 \text { m (electrofishing, } 2106 \mathrm{~m} \text { ) } \\
12.65 / 100 \text { m (electrofishing, } 2106 \mathrm{~m} \text { ) } \\
1.33 / 100 \mathrm{~m} \text { (electrofishing, } 2106 \mathrm{~m} \text { ) } \\
\text { 33 ARGR (various methods, effort } \\
\text { unreported) }\end{array}$ & $\begin{array}{l}\text { Antoniuk and Carey } \\
1979 \\
\text { Antoniuk and Carey } \\
1979 \\
\text { O'Neil et al. } 1988 \\
\text { O'Neil et al. } 1988 \\
\text { O'Neil et al. } 1988 \\
\text { O'Neil et al. } 1988 \\
\text { O'Neil et al. } 1988 \\
\text { Aquatic } \\
\text { Environments } \\
\text { Limited (AEL) } \\
\text { 1975 }\end{array}$ & $\begin{array}{l}\text { site } 1 \text {, pop. est. }=<1 / 100 \mathrm{~m} \\
\text { site } 2 \text {, pop. est. }=2-3.5 / 100 \mathrm{~m} \\
\text { site } 3 \text {, pop. est. }=1 / 100 \mathrm{~m} \\
\text { site } 4 \text {, pop. est. }=12.7-25.8 / 100 \mathrm{~m} \\
\text { site } 5 \text {, pop. est. }=1-10.1 / 100 \mathrm{~m} \\
\text { some of these fish were caught in } \\
\text { the Pembina }\end{array}$ \\
\hline Coal Creek & $\begin{array}{l}\text { 1 ARGR (electrofishing, effort } \\
\text { unknown) }\end{array}$ & AEL 1975 & \\
\hline $\begin{array}{l}\text { Crooked } \\
\text { Creek }\end{array}$ & $\begin{array}{l}1 \text { ARGR (electrofishing, effort } \\
\text { unknown) } \\
1 \text { ARGR (angling, effort unknown) }\end{array}$ & $\begin{array}{l}\text { Antoniuk and Carey } \\
1979 \\
\text { Gulf Canada } \\
\text { Resources } 1980\end{array}$ & \\
\hline $\begin{array}{l}\text { Hanson } \\
\text { Creek }\end{array}$ & $\begin{array}{l}14.33 / 100 \mathrm{~m} \text { (electrofishing, } 300 \mathrm{~m}) \\
5.50 / 100 \mathrm{~m} \text { (electrofishing, } 200 \mathrm{~m}) \\
0.10 / \mathrm{m}(38,51-\mathrm{mm} \text { gill net) }\end{array}$ & $\begin{array}{l}\text { Seidel } 1983 \\
\text { Seidel } 1983 \\
\text { Seidel } 1983\end{array}$ & $\begin{array}{l}\text { phase II } \\
\text { phase II } \\
\text { phase II }\end{array}$ \\
\hline
\end{tabular}


Appendix 5. Summary of Arctic grayling abundance data in the Little Smoky River sub-basin. The sources of this information are Alberta Sustainable Resource Development reports, memos and files, as well as environmental consultants studies produced for industry, stakeholder groups or government (taken from Bryski 1998).

\begin{tabular}{|c|c|c|c|}
\hline Stream & ARGR abundance (method \& effort) & Source & Comments \\
\hline $\begin{array}{l}\text { Little Smoky } \\
\text { River }\end{array}$ & $\begin{array}{l}0.178 / 100 \mathrm{~m} \text { (electrofishing, } 2250 \mathrm{~m} \text { ) } \\
1.00 / \mathrm{hr} \text { (angling, } 2 \text { hours) } \\
6.07 / \mathrm{hr} \text { (angling and tagging, } 156.4 \text { hours) } \\
11.05 / \mathrm{hr} \text { (angling, } 109.7 \text { hours) } \\
0.04 / \mathrm{m} \text { (63 mm gill net, effort?) } \\
0.01 / \mathrm{hr} \text { (angling, } 137.75 \text { hours) } \\
5.46 / \mathrm{hr} \text { (angling, } 71 \text { hours) } \\
4.00 / \mathrm{hr} \text { (angling, } 205.75 \text { hours) } \\
5.59 / \mathrm{hr} \text { (angling, } 358 \text { hours) } \\
5.91 / \mathrm{hr} \text { (angling, } 101 \text { hours) }\end{array}$ & $\begin{array}{l}\text { Fernet and Kratt } \\
1980 \\
\text { Fernet and Kratt } \\
1980 \\
\text { Sterling and Hunt } \\
1989 \\
\text { Sterling and Hunt } \\
1989 \\
\text { Berndt } 1990 \\
\text { Berndt } 1990 \\
\text { Driscoll } 1990 \\
\text { Hildebrandt and } \\
\text { Hunt } 1992 \\
\text { Sullivan and } \\
\text { Johnson } 1994 \\
\text { Sullivan } 1996\end{array}$ & $\begin{array}{l}\text { winter set-lines } \\
\text { Alberta Forestry crew } \\
\text { population estimate } 171 \pm 56 \\
\text { ARGR }(>20 \mathrm{~cm} \text { TL }) / \mathrm{km}, \\
92 \pm 46 \text { in one pool }\end{array}$ \\
\hline $\begin{array}{l}\text { Waskahigan } \\
\text { River }\end{array}$ & $\begin{array}{l}11 \text { ARGR (electrofishing, effort unknown) } \\
5 \text { ARGR ( } 38 \mathrm{~mm}, 76 \mathrm{~mm} \text { gill nets) } \\
10 \text { ARGR (trap, effort unknown) } \\
1 \text { ARGR (seining, effort unknown) } \\
56 \text { ARGR (angling, effort unknown) }\end{array}$ & $\begin{array}{l}\text { Brilling } 1985 \\
\text { Brilling } 1985 \\
\text { Brilling } 1985 \\
\text { Brilling } 1985 \\
\text { Brilling } 1985\end{array}$ & \\
\hline Tony Creek & $\begin{array}{l}\text { 5.10/100 m (electrofishing, } 1825 \mathrm{~m} \text { ) } \\
\text { 7.88/hr (angling, } 8 \text { hours) } \\
\text { 26 ARGR (seining, dip netting, } \\
\text { electrofishing, effort unknown) }\end{array}$ & $\begin{array}{l}\text { Sterling } 1987 \text { a } \\
\text { Sterling } 1987 a \\
\text { AEL } 1975\end{array}$ & $\begin{array}{l}\text { phase II } \\
\text { phase II }\end{array}$ \\
\hline $\begin{array}{l}\text { Unnamed } \\
\text { (Twin City) } \\
\text { Creek (3- } \\
1-61-21-W 5)\end{array}$ & $\begin{array}{l}2.33 / 100 \mathrm{~m} \text { (electrofishing, } 300 \mathrm{~m}) \\
0.07 / \mathrm{m}(64 \mathrm{~mm} \text { gill net })\end{array}$ & $\begin{array}{l}\text { Sterling } 1987 b \\
\text { Sterling } 1987 b\end{array}$ & $\begin{array}{l}\text { phase II } \\
\text { phase II }\end{array}$ \\
\hline $\begin{array}{l}\text { Bird Creek } \\
(13- \\
5-61-21-W 5)\end{array}$ & $\begin{array}{l}5.22 / 100 \mathrm{~m} \text { (electrofishing, } 300 \mathrm{~m} \text { ) } \\
3.71 / \mathrm{hr} \text { (angling, } 7 \text { hours) } \\
1.00 / 100 \mathrm{~m} \text { (electrofishing, } 300 \mathrm{~m} \text { ) }\end{array}$ & $\begin{array}{l}\text { Sterling } 1987 \mathrm{c} \\
\text { Sterling } 1987 \mathrm{c} \\
\text { Berndt } 1990\end{array}$ & $\begin{array}{l}\text { phase II } \\
\text { phase II }\end{array}$ \\
\hline
\end{tabular}




\begin{tabular}{|l|l|l|l|}
\hline $\begin{array}{l}\text { Unnamed } \\
\text { (South Lake) } \\
\text { Creek (2- } \\
\text { 3-61-22-W5) }\end{array}$ & $8.67 / 100 \mathrm{~m}$ (electrofishing, 300 m) & Sterling 1987d & phase II \\
& $0.27 / \mathrm{m}(38 \mathrm{~mm}$ gill net) & Sterling 1987d & phase II \\
\hline $\begin{array}{l}\text { Unnamed } \\
\text { Creek } \\
(14-17-60- \\
23-W 5)\end{array}$ & $1.67 / 100 \mathrm{~m}$ (electrofishing, 300 m) & Sterling 1987d & phase II \\
\hline
\end{tabular}


Appendix 6. Summary of Arctic grayling abundance data in the Berland River sub-basin. The sources of this information are Alberta Sustainable Resource Development reports, memos and files, as well as environmental consultants studies produced for industry, stakeholder groups or government (taken from Bryski 1997a).

\begin{tabular}{|c|c|c|c|}
\hline Stream & ARGR Abundance (method \& effort) & Source & Comments \\
\hline $\begin{array}{l}\text { Berland } \\
\text { River }\end{array}$ & $\begin{array}{l}\text { 4.7 ARGR/hour (angling, } 6.0 \text { hours) } \\
0.10 \text { ARGR/hour (angling, } 20.0 \text { hours) } \\
0.250 / 100 \mathrm{~m} \text { (electrofishing, } 400 \mathrm{~m} \text { ) } \\
0.05 / \mathrm{min} \text { (electrofishing, } 4958 \mathrm{~s} \text { ) } \\
0.10 / \text { min (electrofishing, } 6874 \mathrm{~s} \text { ) } \\
0.06 / \text { min (electrofishing, } 7812 \mathrm{~s} \text { ) } \\
0.03 / \text { min (electrofishing, } 7510 \mathrm{~s} \text { ) } \\
0.01 / \text { min (electrofishing, } 7838 \mathrm{~s} \text { ) } \\
0.06 / \text { min (electrofishing, } 8320 \mathrm{~s} \text { ) } \\
0.01 / \text { min (electrofishing, } 8943 \mathrm{~s} \text { ) } \\
0.02 / \text { min (electrofishing, } 7176 \mathrm{~s} \text { ) }\end{array}$ & $\begin{array}{l}\text { Hawryluk } 1981 \\
\text { Kauffman } 1992 \\
\text { R.L.\&L. } 1994 \\
\text { Earle } 1996 \\
\text { Earle } 1996 \\
\text { Earle } 1996 \\
\text { Earle } 1996 \\
\text { Earle } 1996 \\
\text { Earle } 1996 \\
\text { Earle } 1996 \\
\text { Earle } 1996\end{array}$ & $\begin{array}{l}\text { single day creel } \\
\text { single day creel } \\
\text { near mouth } \\
\text { km } 0-10 \\
\text { km } 20-30 \\
\text { km } 40-50 \\
\mathrm{~km} 60-70 \\
\mathrm{~km} 80-90 \\
\mathrm{~km} 100-110 \\
\mathrm{~km} 120-130 \\
\mathrm{~km} 140-150\end{array}$ \\
\hline $\begin{array}{l}\text { Wildhay } \\
\text { River }\end{array}$ & $\begin{array}{l}\text { 1 ARGR (angling, effort unknown) } \\
0.043 / 100 \mathrm{~m} \text { (electrofishing, } 4700 \mathrm{~m} \text { ) } \\
0.280 / 100 \mathrm{~m} \text { (electrofishing, } 2500 \mathrm{~m} \text { ) } \\
0.731 / 100 \mathrm{~m} \text { (electrofishing, } 2600 \mathrm{~m} \text { ) }\end{array}$ & $\begin{array}{l}\text { Cunningham } 1960 \\
\text { R.L.\&L. } 1993 \\
\text { R.L.\&L. } 1993 \\
\text { R.L.\&L. } 1993\end{array}$ & $\begin{array}{l}\mathrm{km} 112.5-117.2,6 \text { runs } \\
\mathrm{km} 46.9-48.4,6 \text { runs } \\
\mathrm{km} 32.8-35.4,6 \text { runs }\end{array}$ \\
\hline $\begin{array}{l}\text { Pinto } \\
\text { Creek }\end{array}$ & $\begin{array}{l}15 \text { ARGR (angling, effort unknown) } \\
3 \text { ARGR (angling, effort unknown) }\end{array}$ & $\begin{array}{l}\text { Cunningham } 1960 \\
\text { ARDA } 1970\end{array}$ & \\
\hline $\begin{array}{l}\text { Wroe } \\
\text { Creek }\end{array}$ & $0.667 / 100 \mathrm{~m}$ (electrofishing, $300 \mathrm{~m})$ & Thornton 1983 & phase II \\
\hline Fred Creek & $\begin{array}{l}3 \text { ARGR (angling, effort unknown) } \\
1.333 / 100 \mathrm{~m} \text { (electrofishing, } 300 \mathrm{~m} \text { ) } \\
4 \text { ARGR (angling, effort unknown) }\end{array}$ & $\begin{array}{l}\text { Cunningham } 1960 \\
\text { Hominiuk } 1985 \\
\text { Hominiuk } 1985\end{array}$ & $\begin{array}{l}\text { phase II } \\
\text { phase II }\end{array}$ \\
\hline
\end{tabular}




\section{List of Titles in This Series}

(as of March 2005)

No. 1 Status of the Piping Plover (Charadrius melodus) in Alberta, by David R. C. Prescott. 19 pp. (1997)

No. 2 Status of the Wolverine (Gulo gulo) in Alberta, by Stephen Petersen. 17 pp. (1997)

No. 3 Status of the Northern Long-eared Bat (Myotis septentrionalis) in Alberta, by M. Carolina Caceres and M. J. Pybus. 19 pp. (1997)

No. 4 Status of the Ord's Kangaroo Rat (Dipodomys ordii) in Alberta, by David L. Gummer. 16 pp. (1997)

No. 5 Status of the Eastern Short-horned Lizard (Phrynosoma douglassii brevirostre) in Alberta, by Janice D. James, Anthony P. Russell and G. Lawrence Powell. 20 pp. (1997)

No. 5 Update 2004. Status of the Short-horned Lizard (Phrynosoma hernandesi) in Alberta. Alberta Sustainable Resource Development. 27 pp. (2004)

No. 6 Status of the Prairie Rattlesnake (Crotalus viridis viridis) in Alberta, by Sheri M. Watson and Anthony P. Russell. 26 pp. (1997)

No. 7 Status of the Swift Fox (Vulpes velox) in Alberta, by Susan E. Cotterill. 17 pp. (1997)

No. 8 Status of the Peregrine Falcon (Falco peregrinus anatum) in Alberta, by Petra Rowell and David P. Stepnisky. 23 pp. (1997)

No. 9 Status of the Northern Leopard Frog (Rana pipiens) in Alberta, by Greg Wagner. 46 pp. (1997)

No. 9 Update 2003. Status of the Northern Leopard Frog (Rana pipiens) in Alberta. Alberta Sustainable Resource Development. 61 pp. (2003)

No. 10 Status of the Sprague's Pipit (Anthus spragueii) in Alberta, by David R. C. Prescott. 14 pp. (1997)

No. 11 Status of the Burrowing Owl (Speotyto cunicularia hypugaea) in Alberta, by Troy I. Wellicome. 21 pp. (1997)

No. 12 Status of the Canadian Toad (Bufo hemiophrys) in Alberta, by Ian M. Hamilton, Joann L. Skilnick, Howard Troughton, Anthony P. Russell, and G. Lawrence Powell. 30 pp. (1998)

No. 13 Status of the Sage Grouse (Centrocercus urophasianus urophasianus) in Alberta, by Cameron L. Aldridge. 23 pp. (1998)

No. 14 Status of the Great Plains Toad (Bufo cognatus) in Alberta, by Janice D. James. 26 pp. (1998)

No. 15 Status of the Plains Hognose Snake (Heterodon nasicus nasicus) in Alberta, by Jonathan Wright and Andrew Didiuk. 26 pp. (1998)

No. 16 Status of the Long-billed Curlew (Numenius americanus) in Alberta, by Dorothy P. Hill. 20 pp. (1998)

No. 17 Status of the Columbia Spotted Frog (Rana luteiventris) in Alberta, by Janice D. James. 21 pp. (1998)

No. 18 Status of the Ferruginous Hawk (Buteo regalis) in Alberta, by Josef K. Schmutz. 18 pp. (1999)

No. 19 Status of the Red-tailed Chipmunk (Tamias ruficaudus) in Alberta, by Ron Bennett. 15 pp. (1999)

No. 20 Status of the Northern Pygmy Owl (Glaucidium gnoma californicum) in Alberta, by Kevin C. Hannah. 20 pp. (1999) 
No. 21 Status of the Western Blue Flag (Iris missouriensis) in Alberta, by Joyce Gould. 22 pp. (1999)

No. 22 Status of the Long-toed Salamander (Ambystoma macrodactylum) in Alberta, by Karen L. Graham and G. Lawrence Powell. 19 pp. (1999)

No. 23 Status of the Black-throated Green Warbler (Dendroica virens) in Alberta, by Michael R. Norton. 24 pp. (1999)

No. 24 Status of the Loggerhead Shrike (Lanius ludovicianus) in Alberta, by David R. C. Prescott and Ronald R. Bjorge. 28 pp. (1999)

No. 25 Status of the Plains Spadefoot (Spea bombifrons) in Alberta, by Richard D. Lauzon. 17 pp. (1999)

No. 26 Status of the Trumpeter Swan (Cygnus buccinator) in Alberta, by M. Lynne James. 21 pp. (2000)

No. 27 Status of the Pygmy Whitefish (Prosopium coulteri) in Alberta, by William C. Mackay. 16 pp. (2000)

No. 28 Status of the Short-eared Owl (Asio flammeus) in Alberta, by Kort M. Clayton. 15 pp. (2000)

No. 29 Status of the Willow Flycatcher (Empidonax traillii) in Alberta, by Bryan Kulba and W. Bruce McGillivray. 15 pp. (2001)

No. 30 Status of the Woodland Caribou (Rangifer tarandus caribou) in Alberta, by Elston Dzus. 47 pp. (2001)

No. 31 Status of the Western Spiderwort (Tradescantia occidentalis) in Alberta, by Bonnie Smith. 12 pp. (2001)

No. 32 Status of the Bay-breasted Warbler (Dendroica castanea) in Alberta, by Michael Norton. 21 pp. (2001)

No. 33 Status of the Cape May Warbler (Dendroica tigrina) in Alberta, by Michael Norton. 20 pp. (2001)

No. 34 Status of the Whooping Crane (Grus americana) in Alberta, by Jennifer L. White. 21 pp. (2001)

No. 35 Status of Soapweed (Yucca glauca) in Alberta, by Donna Hurlburt. 18 pp. (2001)

No. 36 Status of the Harlequin Duck (Histrionicus histrionicus) in Alberta, by Beth MacCallum. 38 pp. (2001)

No. 37 Status of the Grizzly Bear (Ursus arctos) in Alberta, by John L. Kansas. 43 pp. (2002)

No. 38 Status of the Wood Bison (Bison bison athabascae) in Alberta, by Jonathan A. Mitchell and C. Cormack Gates. 32 pp. (2002)

No. 39 Status of the Bull Trout (Salvelinus confluentus) in Alberta, by John R. Post and Fiona D. Johnston. 40 pp. (2002)

No. 40 Status of the Banff Springs Snail (Physella johnsoni) in Alberta, by Dwayne A.W. Lepitzki. 29 pp. (2002)

No. 41 Status of the Shortjaw Cisco (Coregonus zenithicus) in Alberta, by Mark Steinhilber. 23 pp. (2002)

No. 42 Status of the Prairie Falcon (Falco mexicanus) in Alberta, by Dale Paton. 28 pp. (2002)

No. 43 Status of the American Badger (Taxidea taxus) in Alberta, by Dave Scobie. 17 pp. (2002)

No. 44 Status of the Yucca Moth (Tegeticula yuccasella) in Alberta. Alberta Sustainable Resource Development. 21 pp. (2002) 
No. 45 Status of the White-winged Scoter (Melanitta fusca deglandi) in Alberta. Alberta Sustainable Resource Development. 15 pp. (2002)

No. 46 Status of the Lake Sturgeon (Acipenser fulvescens) in Alberta. Alberta Sustainable Resource Development. 30 pp. (2002)

No. 47 Status of the Western Silvery Minnow (Hybognathus argyritis) in Alberta. Alberta Sustainable Resource Development. 24 pp. (2003)

No. 48 Status of the Small-flowered Sand Verbena (Tripterocalyx micranthus) in Alberta. Alberta Sustainable Resource Development. 24 pp. (2003)

No. 49 Status of the Brown Creeper (Certhia americana) in Alberta. Alberta Sustainable Resource Development. 30 pp. (2003)

No. 50 Status of the Mountain Plover (Charadrius montanus) in Alberta. Alberta Sustainable Resource Development. 25 pp. (2003)

No. 51 Status of the St. Mary Shorthead Sculpin (provisionally Cottus bairdi punctulatus) in Alberta. Alberta Sustainable Resource Development. 24 pp. (2003)

No. 52 Status of the Stonecat (Noturus flavus) in Alberta. Alberta Sustainable Resource Development. 22 pp. (2003)

No. 53 Status of the Sage Thrasher (Oreoscoptes montanus) in Alberta. Alberta Sustainable Resource Development. 23 pp. (2004)

No. 54 Status of the Tiny Cryptanthe (Cryptantha minima) in Alberta. Alberta Sustainable Resource Development. 39 pp. (2004)

No. 55 Status of the Slender Mouse-ear-cress (Halimolobos virgata) in Alberta. Alberta Sustainable Resource Development. 27 pp. (2005)

No. 56 Status of the Barred Owl (Strix varia) in Alberta. Alberta Sustainable Resource Development. 15 pp. (2005)

No. 57 Status of the Arctic Grayling (Thymallus arcticus) in Alberta. Alberta Sustainable Resource Development. 41 pp. (2005) 


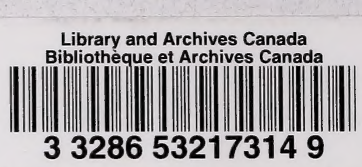

